\title{
IRMPD spectroscopy reveals a novel rearrangement reaction for modified peptides that involves elimination of the $\mathrm{N}$-terminal amino acid
}

Michael J. van Stipdonk ${ }^{1 *}$, Khiry Patterson ${ }^{1}$, John K. Gibson², Giel Berden ${ }^{3}$ and Jos Oomens ${ }^{3,4}$

${ }^{1}$ Department of Chemistry and Biochemistry, Duquesne University, 600 Forbes Ave, Pittsburgh PA 15282 USA

${ }^{2}$ Chemical Sciences Division, Lawrence Berkeley National Laboratory, 1 Cyclotron Road, Berkeley, CA 94720-1150

${ }^{3}$ Radboud University Nijmegen, Institute for Molecules and Materials, FELIX Laboratory, Toernooiveld 7, 6525ED Nijmegen, The Netherlands

${ }^{4}$ University of Amsterdam, Science Park 904, 1098XH Amsterdam

\section{ABSTRACT}

In this study, peptides were derivatized by reaction with salicylaldehyde to create $\mathrm{N}$-terminal imines (Schiff bases). Collision-induced dissociation of the imine-modified peptides produces a complete series of $b$ and $a$ ions (which reveal sequence). However, an unusual pathway is also observed, one that leads to elimination of the residue mass of the $\mathrm{N}$-terminal amino acid despite the chemical modification to create the imine. This pathway was investigated further using infrared multiple-photon dissociation (IRMPD) spectroscopy and density functional theory with alanine-glycine-glycine (AGG) as the test peptide. The IRMPD spectrum for the product generated by loss of 71 from modified AGG (Sal-AGG) matches one predicted for protonated Sal-GG, as well as the IRMPD spectrum of glycine-glycine derivatized independently to produce a Schiff base. We conclude that the residue mass of the N-terminal amino acid is likely eliminated through a pathway that involves nucleophilic attack by an amide $\mathrm{N}$ atom and possible formation of an imidazole-4-one intermediate.

*to whom correspondence should be addressed:

Department of Chemistry and Biochemistry

Duquesne University

600 Forbes Avenue

Pittsburgh, PA 15282

Phone: 412-396-4923

vanstipdonkm@duq.edu

Key words: IRMPD spectroscopy, ion structure, peptide fragmentation, tandem MS, collision-induced dissociation 


\section{INTRODUCTION}

Tandem mass spectrometry (MS/MS) and collision-induced dissociation (CID) remain two of the most important tools used for peptide and protein identification in proteomics ${ }^{1-13}$. Sequencing, whether done by comparison to known peptide fragmentation patterns, or by searching sequence databases with bioinformatics tools that attempt to predict fragmentation, is dependent, in part, on product ion distributions generated by CID ${ }^{14}$. Therefore, a clear understanding of peptide fragmentation mechanisms, energetics and dynamics is necessary to maximize the effectiveness of MS/MS based identification.

Under low-energy CID conditions, fragmentation of protonated peptides traditionally involves charge (proton) mediated reactions, in which cleavage of amide bonds leads to generation of $b, y$, and $a$ ions $^{14-17}$. Development of the mobile proton model ${ }^{18,19}$ of peptide fragmentation, and related amide bond cleavage pathways ${ }^{19-28}$, has been focused primarily on proton mobilization. The pathways in competition (PIC) fragmentation mode ${ }^{14}$ uses the mobile proton model as a foundation for understanding, but takes into account the structures and reactivity of key reactive configurations and primary fragments as well as transition states and their energies.

It has been shown that small (i.e. three or fewer residues within the fragment) N-terminal $b_{\mathrm{n}}$ type fragment ions have structures that include C-terminal oxazolone rings $\mathrm{s}^{20,21,23,29-34}$ and retain the primary sequence of the precursor peptide ion. More recent experiments ${ }^{35-57}$ strongly suggest that macro-cyclic $b$ ion isomers, or intermediates, can arise through cyclization of linear, oxazolone-terminated $b$ ions. For example, in a detailed experimental and theoretical study ${ }^{37}$, the gas-phase structures and fragmentation pathways of the N-terminal $b$ and $a$ fragments of YAGFL-NH2, AGLFY-NH2, GFLYA-NH2, FLYAG-NH2, and LYAGF-NH 2 were investigated using CID and detailed molecular mechanics and density functional theory (DFT) calculations. It was shown that low-energy CID of the $b_{5}$ fragments of the pentapeptide amides produced nearly the same dissociation patterns. Furthermore, CID of protonated cyclo-(YAGFL) produced the same fragments with nearly identical ion abundances to those observed for the $b_{5}$ ions when using similar experimental conditions. The results strongly suggested that rapid cyclization of the primarily linear $b_{5}$ ions can take place, and that the CID spectrum is influenced by the fragmentation behavior of the cyclic isomer.

The extent to which sequence scrambling reactions influence the accuracy of peptide and protein identification by tandem MS has been debated ${ }^{58-61}$. It is important to recognize that the (negative) influence of sequence scrambling on peptide identification is likely to be highest during multiple-stage (MS3 ${ }^{3}$ or higher) CID experiments in 3D or linear ion traps. Indeed, the first identification of potential 
scrambling pathways was made at the $\mathrm{MS}^{3}$ stage $^{62}$. It has been noted that modification of the N-terminus, such as through acetylation ${ }^{37,38}$ or conversion to trimethylpyridinium ion ${ }^{63}$, reduces or eliminates the cyclization that leads to sequence scrambling. Our past examination using YAGFL-NH2 and permuted sequence isomers suggested that sequence scrambling is initiated by nucleophilic attack by the Nterminal amine, upon a carbon atom within the oxazolone ring of a $b_{\mathrm{n}}$ ion, to produce a macrocyclic isomer ${ }^{37}$. Opening of the macrocycle at various positions leads to the loss of sequence information. The prevention of sequence scrambling with acetylation, for example, can be attributed to the fact that the nucleophilic amino group is converted to an amide (or otherwise functionalized if other modification is made).

In an attempt to identify ways to mitigate effects of sequence scrambling pathways and enhance $\mathrm{MS}^{\mathrm{n}}$ approaches to direct peptide identification, we have been investigating several derivatization strategies. Our goal is to derivatize the N-terminus of peptide, efficiently and quantitatively (thus eliminating the amine nucleophile responsible for the scrambling reactions) while maintaining a basic site to enhance ionization (protonation) efficiency. As part of these studies, one approach taken was to convert the $\mathrm{N}$-terminus to an imine (Schiff base) by condensation with an aldehyde (scheme 1). In our preliminary experiments, we found that an extensive series of $b_{\mathrm{n}}$ and $a_{\mathrm{n}}$ ions are produced by CID, and that the $\mathrm{N}$-terminal product ions dominate C-terminal fragments such as the $y_{n}$ ions (likely reflecting the high basicity of the imine group). In addition, sequence scrambling pathways were apparently suppressed or eliminated altogether. More importantly, we also observed a fragmentation reaction that appeared to involve elimination of the residue mass of the $\mathrm{N}$-terminal amino acid, despite the chemical modification to create the imine. The pathway therefore reflects another interesting and unanticipated rearrangement reaction and is the subject of the present study. Here, we report the general fragmentation patterns of the derivatized peptides that helped identify the new rearrangement, and the use of IRMPD spectroscopy and density functional theory calculations to shed light on the reaction pathway that leads to the elimination of the residue mass of the $\mathrm{N}$-terminal residue.

\section{EXPERIMENTAL METHODS}

\section{Sample preparation}

Peptides (glycine-glycine-glycine, alanine-glycine-glycine, glycine-glycine-alanine, valinealanine-alanine-phenylalanine and tyrosine-glycine-glycine-phenylalanine-leucine) were purchased from Sigma Aldrich (St. Louis, MO) and used as received. Peptide imines were generated by reacting peptides with salicylaldehyde $\left(1: 1\right.$ mole ratio) in methanol for $2-6$ hours at $37^{\circ} \mathrm{C}$. The reaction mixture was then 
diluted with 50:50 methanol/water and then acidified with $10 \mu \mathrm{L}$ of $1 \%$ acetic acid in $\mathrm{H}_{2} \mathrm{O}$. Modification of the respective peptides was confirmed by a mass shift of 104 mass units $(u)$, the expected change due to the condensation reaction. Final peptide concentrations for ESI-MS and IRMPD studies were $\sim 10^{-4} \mathrm{M}$.

\section{Collision-induced dissociation experiments}

Ion trap multiple-stage CID experiments were conducted on a ThermoScientific LTQ-XL linear ion trap mass spectrometer (Themo Scientific, San Jose, CA, USA). The atmospheric pressure ionization stack settings for the LCQ (lens voltages, quadrupole and octapole voltage offsets, etc.) were optimized for maximum $(\mathrm{M}+\mathrm{H})^{+}$transmission to the ion trap mass analyzer using the auto-tune routine within the LTQ Tune program. Following the instrument tune, the spray needle voltage was maintained at $+5 \mathrm{kV}$, the $\mathrm{N}_{2}$ sheath gas flow at 10 units (arbitrary for the ThermoScientific instruments) and the capillary (desolvation) temperature at $200^{\circ} \mathrm{C}$. Helium was used as the bath/buffer gas to improve trapping efficiency and as the collision gas for CID experiments.

The CID studies (MS/MS and MSn) were performed as follows. The $(\mathrm{M}+\mathrm{H})^{+}$ions were isolated for the initial CID stage (MS/MS) using an isolation width of 0.9 to $1.2 \mathrm{~m} / \mathrm{z}$ units. The exact wid th was chosen empirically and reflected the best compromise between high $(\mathrm{M}+\mathrm{H})^{+}$abundance and the isolation of a single isotopic peak. The (mass) normalized collision energy, which defines the amplitude of the R.F. energy applied to the end cap electrodes in the CID experiment, was set between 20 and 25\%, which corresponds roughly to $0.80-0.99 \mathrm{~V}$ with the instrument calibration used in this study). The activation $\mathrm{Q}$ (as labeled by ThermoFinnigan, used to adjust the $\mathrm{q}_{\mathrm{z}}$ value for the precursor ion) was set at 0.30 . The activation time employed at each CID stage was $30 \mathrm{~ms}$.

\section{ESI FT-ICR mass spectrometry}

Previously established methods were used for generation of ions and the subsequent collection of IRMPD spectra [26-30]. Briefly, ESI was performed using a Micromass Z-Spray source. Ions were injected into a home-built Fourier transform ion cyclotron resonance (FT-ICR) mass spectrometer described in detail elsewhere ${ }^{64}$. Instrument operating parameters, such as desolvation temperature, cone voltage, and ion accumulation and transfer optics voltages, were optimized to maximize formation of $(\mathrm{M}+\mathrm{H})^{+}$ions, or $\mathrm{b}_{2}$ ions generated by in-source CID, and transfer of the species to the ICR cell. Dry nitrogen $\left(\sim 80^{\circ} \mathrm{C}\right)$ was used to assist in the desolvation process. Ions were accumulated for the duration of the previous FT-ICR cycle (approximately $5 \mathrm{~s}$ ) in an external hexapole and injected into the ICR cell via a quadrupole deflector and an octapole RF ion guide. 
Infrared Multiple Photon Dissociation (IRMPD)

Infrared spectra were recorded by measuring the photodissociation yield as a function of photon wavelength. Precursor ions were irradiated using two FELIX macropulses ( $35 \mathrm{~mJ}$ per macropulse, $5 \mu \mathrm{s}$ pulse duration, FWHM bandwidth $\sim 0.5 \%$ of central $\lambda$ ). In the IRMPD process, photon absorption occurs when the laser frequency matches a vibrational mode, and energy is subsequently distributed over all vibrational modes by intramolecular vibrational redistribution (IVR). The IVR process allows the energy of each photon to be dissipated before the ion absorbs another, and this process promotes ion internal energy toward the dissociation threshold via multiple photon absorption ${ }^{65}$. It is important to note that infrared spectra obtained using IRMPD are comparable to those collected using linear absorption techniques ${ }^{66,67}$. For the current experiments, the free electron laser wavelength was tuned between 6.25 and $11.2 \mu \mathrm{m}$ in 0.04 to $0.1 \mu \mathrm{m}$ increments. The intensity of product and un-dissociated precursor ions was measured using the excite/detect sequence of the FT-ICR-MS after each IRMPD step. The IRMPD yield was normalized to the total ion current, and linearly corrected for variations in laser power across the wavelength range scanned. In the figures shown below, the IRMPD spectra are normalized to facilitate comparison of intensity to predictions by DFT. The overall photodissociation yields for the ions investigated were above $10-15 \%$, and we assume that the IRMPD spectra reflect the true ion populations, without bias due to differences in dissociation thresholds for different isomers.

\section{DFT Geometry and Frequency Calculations}

All DFT calculations were performed using the Gaussian 03 group of programs ${ }^{68}$. Full geometry optimizations for Sal-AGG and various potential structures created by elimination of 71 mass units $(\mathrm{u})$ from the derivatized peptides were initiated using the hybrid B3LYP functional and the $3-21 \mathrm{G}^{*}$ basis set on all atoms. The same was done for $b_{2}{ }^{+}$from Sal-AGG, and for intact salicylaldehyde-derivatized GG (Sal-GG). Using the minima identified at this level of theory, relaxed scans were performed by rotating (through $360^{\circ}$ ) dihedral angles along the backbone in $3^{\circ}$ steps to continue the search for alternative structures. Minima identified were then re-optimized using the same functional and the $6-311+G(d, p)$ basis set. Vibrational spectra and (zero-point corrected) relative energies were computed at the same level of theory. The vibrational frequencies are scaled by a factor of 0.98 . This scaling factor was chosen empirically to produce a good correlation of peak positions in the experimental and theoretical IR spectra $^{32,69}$. 


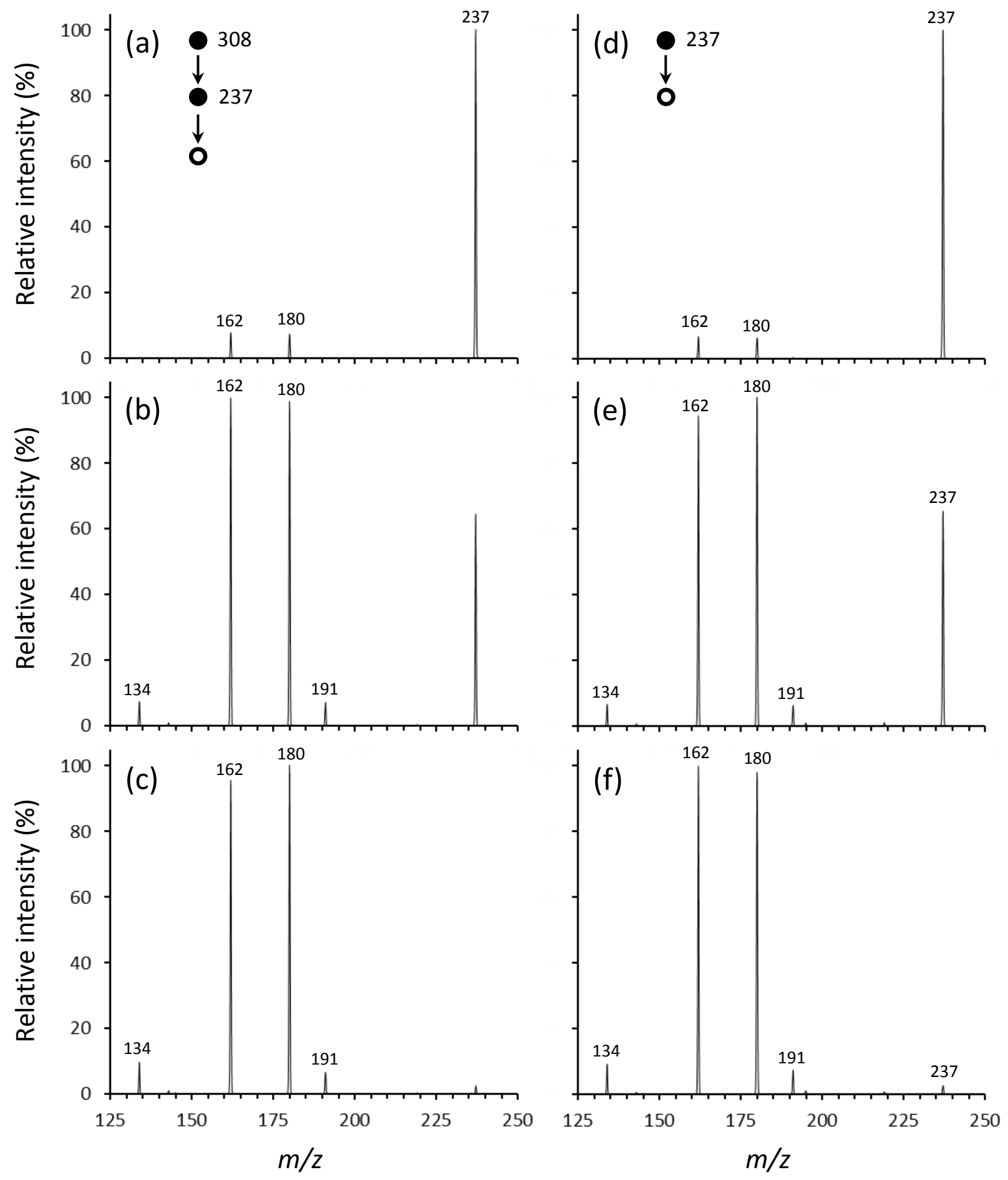

Figure S4. 


\section{RESULTS AND DISCUSSION}

\section{CID of Derivatized Peptides and Identification of New Fragmentation Pathway}

We begin our discussion with the CID spectra derived from underivatized GGG, AGG and GGA, which because of their relative simplicity are provided in figure S1 of the supporting information. For each peptide, the most abundant peak generated by CID is $b_{2}{ }^{+}$, at m/z 115 for GGG and GGA, and m/z 129 for AGG. The N-terminus containing $b$ ions, in general, are formed via the "oxazolone" pathway14,20,21,29 as shown in scheme 2a. An oxazolone structure for $b_{2}$ ions generated from protonated tripeptides has been confirmed by several IRMPD/DFT studies ${ }^{31,32,70}$. Also observed for each peptide was $a_{2}{ }^{+}(\mathrm{at} \mathrm{m} / \mathrm{z} 87$ for GGG and AGG, m/z 101 for GGA) at relative intensity less than 10\%.

The C-terminus containing $y$ ions are less abundant, in general, from the tripeptides used here. A small peak $(<10 \%)$ corresponding to formation of $y_{2}{ }^{+}$was observed for protonated AGG, and is likely formed along the $y$ - $a$ pathway outlined by Paizs and Suhai ${ }^{28}$. A prominent peak corresponding to $y_{1^{+}}$(the complementary ion to $b_{2}{ }^{+}$) was observed for protonated GGA.

Other fragmentation pathways common to the three tripeptides involved the loss of $\mathrm{H}_{2} \mathrm{O}$ or elimination of $\mathrm{CO}$ and $\mathrm{NH}_{3}$. Loss of $\mathrm{H}_{2} \mathrm{O}$ represents either generation of $b_{3}{ }^{+}$through the oxazolone pathway, or formation of an imidazole-one product through rearrangement and loss of an amide $\mathrm{O}$ atom. The later pathway has been invoked to explain loss of $\mathrm{H}_{2} \mathrm{O}$ from protonated tetraglycine ${ }^{71,72}$. Data from IRMPD spectroscopy and DFT calculations ${ }^{73}$ support a mechanism for this rearrangement that involves nucleophilic attack by an amide $\mathrm{N}$ atom, with associated proton transfer, to generate the imidazole-one. The pathway by which $\mathrm{CO}$ and $\mathrm{NH}_{3}$ are eliminated was investigated by Bythell et al, who used tandem MS, isotope labeling and DFT to determine the mechanisms behind backbone cleavages and elimination of small molecules from protonated $\mathrm{AGG}^{74}$. Based on comprehensive DFT calculations, it was suggested that initial loss of $\mathrm{CO}$ is likely followed by rearrangement and elimination of $\mathrm{NH}_{3}$ to leave a peptide fragment with an $\mathrm{N}$-terminal imine group.

We next examined the fragmentation of derivatized versions of the three tripeptides. The CID spectra generated from GGG, AGG and GGA, after derivatization with salicylaldehyde to create the imines, are shown in figure 1. It is immediately clear from a comparison of the spectra in figures S1 (supporting information) and 1 that CID of the derivatized peptides produces a wider array of sequence ions. Particularly interesting is the appearance of product ions that are formally $b_{1}$ species generated by cleavage of the N-terminal amide bond. Normally, $b_{1}$ ions are not observed and their absence was used as early supporting evidence for the oxazolone structure of $b$ ions in general20,21,29. For example, 
generation of $b_{2}{ }^{+}$with an oxazolone structure from a protonated tripeptide requires the nucleophilic attack by an amide carbonyl group located to the $\mathrm{N}$-terminal side of the cleavage site (scheme 2a). In the present case, $b_{1}$ ions are clearly generated despite the lack of the required amide nucleophile. The structure of the $b_{1}$ ion, and the pathway by which they are generated, is not immediately clear and is currently under further investigation.

The CID spectrum of the imine-derivatized peptides is dominated by the N-terminus containing $b_{\mathrm{n}}$ and $a_{\mathrm{n}}$ ions. Only $y_{2}{ }^{+}$is present in the product ion distribution for each peptide. The $y_{3}$ ion would be formed by cleavage of the imine $\mathrm{C}=\mathrm{N}$ bond, with associated proton transfer, to cause elimination of $105 \mathrm{u}$. This neutral loss was not observed for any of the derivatized peptides. The $y_{1}$ ion, which was prominent in the CID spectrum of underivatized GGA, has an $\mathrm{m} / \mathrm{z}$ value of 90 , which falls below the low-mass cutoff (LMCO) of the linear ion trap. Therefore, though the $y_{1}$ ions may in fact be created by CID, they were not observed in these experiments because of the imposed cut-off. The LMCO is defined, in part, by the activation $Q$ setting on the ion trap and can be decreased by setting $Q$ to a lower value. This was attempted in the present study to place the LMCO well below m/z 90 to search for $y_{1}$ from derivatized GGA. However, decreasing the value of $Q$ also decreased the trapping efficiency and severely attenuated the product ion signal.

More interesting and important is the peak in figure 1a (from Sal-GGG) that corresponds to the apparent loss of $57 \mathrm{u}$ from $(\mathrm{M}+\mathrm{H})^{+}$. We initially attributed this peak to formation of the $b_{2}+\mathrm{H}_{2} \mathrm{O}$ ion. These species are often observed protonated peptides that contain one or more arginine residues ${ }^{75-77}$ and analogous $\left(\mathrm{b}_{\mathrm{n}}+17+\mathrm{Cat}\right)^{+}$are frequently observed for metal $\left(\mathrm{Li}^{+}, \mathrm{Na}^{+}\right.$or $\left.\mathrm{Ag}^{+}\right)$cationized peptides ${ }^{78-87}$. An anhydride mechanism, shown for protonated Sal-GGG in scheme $2 b$, has been postulated for generation of $b_{2}+\mathrm{H}_{2} \mathrm{O}$ and $\left(b_{\mathrm{n}}+17+\mathrm{Cat}\right)^{+}$ions ${ }^{88,89}$. The absence of both an arginine residue and metal cation in the present case made the appearance of such a species an unexpected result.

As shown in figure $1 \mathrm{~b}$, however, the neutral loss of $57 \mathrm{u}$ shifts to $71 \mathrm{u}$ for Sal-AGG, but remained $57 \mathrm{u}$ for Sal-GGA. The shift of neutral loss observed within the group of peptides therefore suggests a fragmentation reaction that involves elimination of the residue mass of the $\mathrm{N}$-terminal residue. A minor peak that we can attribute to the anhydride mechanism (and therefore generation of $b_{2}+\mathrm{H}_{2} \mathrm{O}$ ) is present in the spectra shown in figures $1 \mathrm{~b}$ and $1 \mathrm{c}$ (loss of $57 \mathrm{u}$ and $71 \mathrm{u}$ for modified AGG and GGA, respectively).

Possible mechanisms to explain the elimination of the $\mathrm{N}$-terminal residue from the modified peptides are shown in pathways $\mathbf{a}$ and $\mathbf{b}$ of scheme 3 . In pathway $\mathbf{a}$, the reaction is initiated by proton transfer from the imine $\mathrm{N}$ atom ultimately to the $\mathrm{O}$ atom of the $\mathrm{C}$-terminal amide group. The proton transfer is followed by nucleophilic attack by the imine $\mathrm{N}$ atom upon the $\mathrm{C}$ atom of the $\mathrm{C}$-terminal amide 
group to create a substituted ketopiperazine intermediate. Collapse of this intermediate, with ejection of an aziridinone, leaves a product ion with backbone hydroxyaziridine ring.

In pathway $\mathbf{b}$, the $\mathrm{N}$ atom of the imine group remains protonated. The rearrangement is initiated by nucleophilic attack by the $\mathrm{N}$ atom of the middle amide group upon the $\mathrm{C}$ atom of the $\mathrm{N}$-terminal imine, and ultimately generates an imidazol-one intermediate. Opening of the ring intermediate, with ejection of $\mathrm{CO}$ and an imine, results in formation of an imine-derivatized peptide that is one amino acid smaller. The attack by the amide $\mathrm{N}$ atom and formation of the imidazole-one intermediate is similar to the steps proposed to explain the elimination of $\mathrm{H}_{2} \mathrm{O}$ from protonated tetraglycine ${ }^{71-73}$. Therefore, there is precedent for nucleophilic attack by amide $\mathrm{N}$ atoms during rearrangement reactions of gas-phase peptide ions.

We also examined and compared the fragmentation behavior of unmodified and modified VAAF and YGGFL (leucine-enkephalin). Our attention on the general product ion distribution and whether or not a product ion was observed that is consistent with the pathway that leads to elimination of the reside mass of the N-terminal amino acid. The CID spectra for VAAF and Sal-VAAF are shown in figure 2a and $2 b$, respectively. The most abundant fragment ion for the underivatized version is $y_{2} a t m / z 237$, and less abundant $y_{3}$ and $y_{1}$ ions are also observed at $\mathrm{m} / \mathrm{z} 308$ and 166, respectively. The $\mathrm{N}$-terminus-containing $\mathrm{b}_{3}$, $\mathrm{b}_{2}$ and $\mathrm{a}_{2}$ ions are observed at $\mathrm{m} / \mathrm{z} 242,171$, and 143, respectively. The CID spectrum for Sal-VAAF, is markedly different in that the most abundant product ion is $b_{3}$ at $\mathrm{m} / \mathrm{z} 346$. As observed for the tripeptides described above, the C-terminus containing $y_{\mathrm{n}}$ ion series is diminished in intensity for imine-modified $\mathrm{VAAF}$ and the fragment ion distribution is dominated by the $b_{\mathrm{n}} / a_{\mathrm{n}}$ series. Important to this study, fragmentation pathways that result in elimination of the residue masses of the C-terminal and $\mathrm{N}$-terminal amino acids (F and V at 147 and $99 \mathrm{u}$, respectively) are also observed, but with significantly lower relative intensities that for the smaller protonated tripeptides.

The general fragmentation pattern of protonated YGGFL (and variants) is known as it has been widely used in fundamental studies of peptide fragmentation ${ }^{37,90-93}$. The CID spectra of unmodified and modified YGGFL (leucine-enkephalin) are shown in figure $3 \mathrm{a}$ and $3 \mathrm{~b}$. The $b_{4}$ and $a_{4}$ ions are most abundant product ions, and peaks that can be assigned to $b_{3}, b_{2}, y_{3}$ and $y_{2}$ are also observed. An important study by Vachet and coworkers demonstrated that rearrangement reactions for protonated YGGFL are activated under low-energy CID conditions, and they lead to the apparent elimination of internal amino acid residues ${ }^{93}$. The product ions generated by these rearrangement reactions therefore contain no sequence-specific information, and their mechanistic details were the subject of a comprehensive isotopelabeling and DFT investigation ${ }^{90}$. The peaks in figure that can be attributed to these rearrangement 
reactions with asterisks. As is clear from inspection of the CID spectrum for Sal-YGGFL in 3b, similar "rearranged" product ions are not generated from the imine-modified peptide, and the product ion distribution is dominated by N-terminal $b_{\mathrm{n}} / a_{\mathrm{n}}$ series. As discussed above for imine-modified VAAF, fragmentation pathways that result in elimination of the residue masses of the C-terminal and N-terminal amino acids ( $\mathrm{Y}$ and $\mathrm{L}$ at 163 and $113 \mathrm{u}$, respectively) are also observed.

\section{IRMPD Spectroscopy to Determine Product Generated by Loss of 71 u from Sal-AGG}

In an attempt to more clearly resolve the pathway by which the residue mass of the N-terminal amino acid is eliminated from the imine-modified peptides, we used IRMPD spectroscopy to determine the structure of precursor and product ions using Sal-AGG as a model. For intact, protonated Sal-AGG, several minima were identified by DFT calculations, including structures in which the imine $\mathrm{N}$ atom is protonated and those for which amide $\mathrm{O}$ atoms are the protonation site. The four lowest energy structures are shown in figure 4 . Relative energies for the respective species are provided in table 1.

The lowest energy structure (I) is protonated at the imine $\mathrm{N}$ atom and features a $\beta$-strand type conformation. The next highest energy structure (II) is also protonated at the imine nitrogen atom, but a change of dihedral angle allows for a hydrogen bonding interaction between the imine and the Cterminal amide $\mathrm{O}$ atom. The amide $\mathrm{O}$ atom protonated (so called charge solvated) structures (III and IV) are $9.5-16.2 \mathrm{kcal} / \mathrm{mol}$ higher in energy than structure $\mathbf{I}$, as are several other amide $\mathrm{O}$ and amide $\mathrm{N}$ protonated species (not shown).

Figure 5 compares the IRMPD spectrum of Sal-AGG (figure 5a) to those predicted for structures I and III (the lowest energy imine $\mathrm{N}$ and amide $\mathrm{O}$ protonated species, figures $5 \mathrm{~b}$ and $\mathrm{c}$, respectively). A comparison of the IRMPD spectrum to those predicted by DFT for structures II and IV is provided in figure S2 of the supporting information. Comparison of the spectra in figure 4 shows that the agreement between IRMPD and theoretical spectra is best for species I, and strongly suggests that the imine-N protonated, $\beta$-strand conformation represents the intrinsic structure of protonated Sal-AGG.

Assignments of vibrational modes can be made using the comparison of IRMPD and predicted spectrum for structure $\mathbf{I}$. The feature at $1776 \mathrm{~cm}^{-1}$ is assigned to the $\mathrm{C}=\mathrm{O}$ stretch of the $\mathrm{C}$-terminal acid group. The absorption from $1686 \mathrm{~cm}^{-1}$ to $1739 \mathrm{~cm}^{-1}$ corresponds to two unresolved vibrations, which are symmetric and asymmetric combinations of the amide $\mathrm{C}=\mathrm{O}$ stretches (amide I band). The feature at 1652 $\mathrm{cm}^{-1}$ is assigned to the imine $\mathrm{C}=\mathrm{N}$ stretch. The broad, partially resolved pair of vibrations at $1574 \mathrm{~cm}^{-1}$ and $1605 \mathrm{~cm}^{-1}$ is attributed to $\mathrm{C}-\mathrm{C}$ stretches of the salicyl group, with and without coupling to ring $-\mathrm{OH}$ 
and imine $\mathrm{N}-\mathrm{H}$ wags. The intense absorption at $1510 \mathrm{~cm}^{-1}$ is assigned to the amide $\mathrm{N}-\mathrm{H}$ wag (amide II vibration).

We next turned our attention to the structure of the product ion generated by loss of $71 \mathrm{u}$ from protonated Sal-AGG. Minima identified using DFT for products generated through path $\mathbf{a}$ and $\mathbf{b}$ (scheme 3) are shown in figure 6. Relative energies for the respective species are provided in table 1. As noted earlier, the product ion generated in pathway a, through a potential ketopiperazine intermediate, would have a hydroxyaziridine structure. Both structures V and VII feature intact hydroxyaziridine rings. We found during dihedral scans of structure $\mathbf{V}$ that eliminated several intramolecular hydrogen bonding interactions causes the aziridine ring to open and create a structure that is actually salicylaldehydemodified GG, but with the amide bond in a cis configuration and the amide $\mathrm{O}$ atom protonated (structure VI).

The products generated by pathway $\mathbf{b}$, which is proposed to involve the formation of an imidazol-one intermediate, would instead be conformational isomers of Sal-GG with trans-conformation amide bond. The three lowest energy structures identified for Sal-GG are shown in figure 6 (relative energies provided in table 1). As for Sal-AGG, the lowest energy structure for Sal-GG is a $\beta$-strand conformation, with the imine $\mathrm{N}$ atom serving as the protonation site (structure VIII) . Structure IX has a change of dihedral angle to break the intramolecular hydrogen bond. Though the calculations predict that the change in conformation has an energetic cost of $2.4 \mathrm{kcal} / \mathrm{mol}$, this value may lie within the error expected when using DFT. The lowest energy O protonated structure $(X)$ lies $16.5 \mathrm{kcal} / \mathrm{mol}$ higher in energy. It is important to note structures VIII, IX and $\mathbf{X}$ are $10.8-56.4 \mathrm{kcal} / \mathrm{mol}$ lower in energy that those that may be generated through pathway a.

The IRMPD spectrum generated from the product ion created by loss of $71 \mathrm{u}$ from protonated Sal-AGG is shown in figure 7a, and compared to the lowest energy structures predicted for pathways a and $\mathbf{b}$, structures VI and VIII, in figures $7 \mathrm{~b}$ and 7c, respectively. Comparisons to the other possible conformations for the product ion (structures V, VII, IX and $\mathbf{X}$ ) are provided in figure S3 of the supporting information. It is clear from the comparison of figures $7 \mathrm{a}, \mathrm{b}$ and $\mathrm{c}$ that there is good general agreement between IRMPD and theoretical spectra for structure VIII, which is Sal-GG protonated at the imine $\mathrm{N}$ atom and featuring a $\beta$-strand conformation.

Based on the initial comparison of IRMPD to theoretical spectra, it appears that the product generated by loss of $71 \mathrm{u}$ from protonated Sal-AGG is protonated Sal-GG. We also reacted salicylaldehde with GG in an independent set of experiments, and collected the IRMPD spectrum of the intact derivatized dipeptide. The IRMPD spectrum collected for Sal-GG, shown in figure 7d, is nearly identical, 
both in terms of the positions and intensities of IR peaks, to the IRMPD spectrum of the dissociation product generated by fragmentation of Sal-AGG. We believe that this confirms that Sal-GG is created by loss of $71 \mathrm{u}$ from Sal-AGG, likely by the pathway that involves the imidazol-one intermediate.

The vibrational modes and assignments for Sal-GG are similar to those for Sal-AGG. The acid $\mathrm{C}=\mathrm{O}$ stretch appears at $1173 \mathrm{~cm}^{-1}$. The amide $\mathrm{C}=\mathrm{O}$ stretch (amide I vibration) is at $1718 \mathrm{~cm}^{-1}$. Because SalGG contains only a single amide bond, no splitting of the amide I band into symmetric and asymmetric combinations of stretching is observed. The imine $C=N$ stretch appears at $1658 \mathrm{~cm}^{-1}$, and salicyl ring C-C stretches within the broad absorption spanning $1567 \mathrm{~cm}^{-1}$ to $1618 \mathrm{~cm}^{-1}$. The amide II band is observed at $1519 \mathrm{~cm}^{-1}$. The peaks in the region $1250 \mathrm{~cm}^{-1}$ to $1450 \mathrm{~cm}^{-1}$ are assigned to different combinations of backbone $-\mathrm{CH}_{2}$ - bend and rock vibrations.

Another obvious test to determine whether the reaction that causes elimination of $71 \mathrm{u}$ from SalAGG does indeed produce Sal-GG is to compare the CID pattern for the product ion to that generated instead from Sal-GG. CID spectra were collected for the $\mathrm{m} / z 237$ generated at the $\mathrm{MS}^{3}$ stage from protonated Sal-AGG ( $\mathrm{m} / \mathrm{z} 308)$ and for the $\mathrm{m} / \mathrm{z} 237$ ion created directly be ESI from Sal-GG using three different normalized collision energies (NCE). As is apparent in the spectra shown in figure S4 of the supporting information, the fragmentation patterns for the two, independently created ions, are essentially identical. Each ion fragments to produce species at $m / z 191,180,162$ and 134, in nearly equal relative intensities, at each NCE used. This observation therefore provides addition support to the hypothesis that Sal-GG is created by loss of $71 \mathrm{u}$ from Sal-AGG.

\section{Determination of the structure of $b_{2}{ }^{+}$from Sal-AGG}

As noted in the introduction section, there is a great deal of IRMPD evidence that small (i.e. 3 or fewer residues within the fragment) $b_{n}$ type fragment ions have structures that include C-terminal oxazolone rings ${ }^{31,32,70}$ and retain the primary sequence of the precursor peptide ion. In the mobile proton model of peptide fragmentation ${ }^{19,94}$, protons added to create a charged ion play a critical role in the fragmentation of protonated peptides during CID. The original model distinguished peptide ions with easily mobilized protons from for which protons are sequestered by highly basic side (for example, at the side chains of lysine or arginine residues). For the former class, collisional activation/excitation drives to proton transfer reactions which populate amide nitrogen protonation sites. This enables facile amide bond cleavage and thus the formation of $b$ and $y$ sequence ions. In contrast, the latter class of peptide ions contains strongly basic functionalities which sequester the ionizing protons, thereby often hindering formation of sequence ions. We and others have demonstrated that amide position protons can 
apparently be mobilized during CID of peptides for which there is no added "mobile" proton" 69,88 . In one case, IRMPD spectroscopy was used to study formation of $b_{2}$ from nicotinyl-glycine-glycine-methyl ester (NicGGOMe). IRMPD shows that NicGGOMe is protonated at the pyridine ring of the nicotinyl group, and more importantly, that $b_{2}$ from NicGGOMe is not protonated at the oxazolone ring, as would be expected if the species were generated on the conventional $b_{\mathrm{n}} / y_{\mathrm{n}}$ oxazolone pathway, but at the pyridine ring instead ${ }^{69}$. IRMPD data support a hypothesis that formation of $b_{2}$ from NicGGOMe involves mobilization and transfer of an amide position proton during the fragmentation reaction.

Later, Bythell and coworkers described proton-driven amide bond cleavages necessary to produce $b$ and $y$ ions from peptide ions lacking easily mobilizable protons ${ }^{88}$, and showed that peptide ions of this type may through three new amide bond cleavage mechanisms which involve salt-bridge, anhydride or imine enol intermediates. All three new mechanisms are less energetically demanding than the classical oxazolone $b-y$ pathway.

The IRMPD spectrum of Sal-AGG showed convincingly that the imine $\mathrm{N}$ is the protonation site for the peptide in the gas-phase, and we hypothesized that the imine-modified peptides might represent another example of species that lack "easily mobilizable protons". In addition, earlier IRMPD studies have shown that the protonation site of $b_{2}$ ions is the oxazolone $\mathrm{N}$ atom. The $b_{2}$ ion derived from SalAGG, however, has both the oxazolone $\mathrm{N}$ atom and the imine $\mathrm{N}$ atom as possible protonation sites. We therefore were interested in the gas-phase structure of $b_{2}+$ from Sal-AGG, and in particular, the protonation site.

The three lowest energy minima identified for $b_{2}{ }^{+}$from Sal-AGG that include an oxazolone ring are structures $\mathbf{X I}, \mathbf{X I I}$ and $\mathbf{X I I I}$ in figure 6. Structure $\mathbf{X I}$ is protonated at the oxazolone $\mathbf{N}$ atom, as it would be as a consequence of the oxazolone pathway and without intramolecular migration of the proton to the imine $\mathrm{N}$ atom. Structures XII and XIII instead are protonated at the imine $\mathrm{N}$ atom but have different dihedral angles and intramolecular hydrogen bonding. Both imine-N protonated structures are lower in energy relative to the oxazolone $\mathrm{N}$ protonated structure (table 1).

The IRMPD spectrum of $b_{2}{ }^{+}$from Sal-AGG is compared in figure 8 to those predicted by DFT for structures XI (figure 8b), XII (figure 8c) and XIII (figure 8d). In general, the agreement is good between experiment and theory for both structures XII and XIII, the two imine-N protonated species. We note the predicted difference in energy between the two structures is only $2.1 \mathrm{kcal} / \mathrm{mol}$, which may be within the error expected at this level of theory.

Using the predicted vibrational spectra, the absorption at $1886 \mathrm{~cm}^{-1}$ in the IRMPD spectrum of $b_{2}{ }^{+}$ from Sal-AGG can be assigned to the $\mathrm{C}=\mathrm{O}$ stretch of the oxazolone ring. The position of the oxazolone 
$\mathrm{C}=\mathrm{O}$ stretch is a sensitive diagnostic for the protonation site. For example, in a previous study of the structure of $\mathrm{b}_{2}{ }^{+}$derived from protonated AGG, the $\mathrm{C}=\mathrm{O}$ appeared at ca. $1970 \mathrm{~cm}^{-1}$ and was in excellent agreement with the position predicted for the oxazolone protonated on the ring nitrogen ${ }^{31}$. A shoulder on the low-frequency side of the $\mathrm{C}=\mathrm{O}$ stretching band suggested a minor contribution from an oxazolone protonated on the free amino $\mathrm{N}$ atom, and this conclusion is supported by a predicted red-shift to the $\mathrm{C}=\mathrm{O}$ stretching frequency. A similar observation was made for $b_{2}{ }^{+}$generated by $\mathrm{CID}$ of protonated trialanine (AAA) ${ }^{32}$. From the better match of the oxazolone $\mathrm{C}=\mathrm{O}$ stretch, experimentally observed at 1950 $\mathrm{cm}^{-1}$, as well as from the substantially better match in the $1400-1800 \mathrm{~cm}^{-1}$ range, clearly the $b_{2}{ }^{+}$fragment of protonated AAA has an oxazolone structure protonated at the oxazolone $\mathrm{N}$-atom. In that same study, two oxazolone protonated conformers were also identified that differ mainly in the torsional angle around the $\mathrm{C}-\mathrm{C}$ bond connecting the oxazolone ring and the backbone. The lowest energy structure gains stability from a hydrogen bond between the proton on the oxazolone nitrogen atom and the Nterminus. However, the calculated spectra for the two oxazolone protonated conformers were similar, and exclusion of one or another structure was difficult based on the IRMPD spectrum.

Returning to the case of $b_{2}{ }^{+}$from Sal-AGG, the features at $1650 \mathrm{~cm}^{-1}$ and $1666 \mathrm{~cm}^{-1}$ are assigned to C-N stretches of the imine and oxazolone groups, respectively. The feature at $1607 \mathrm{~cm}^{-1}$ and lowfrequency shoulder at $1567 \mathrm{~cm}^{-1}$ correspond to the $\mathrm{C}-\mathrm{C}$ stretches of the salicyl ring. The absorptions in the region from $1450 \mathrm{~cm}^{-1}$ to $1550 \mathrm{~cm}^{-1}$ are assigned to ring $\mathrm{C}-\mathrm{C}$ stretches coupled to backbone $\mathrm{C}-\mathrm{CH} 3$ bending motion. The absorptions from $1350 \mathrm{~cm}^{-1}$ to $1450 \mathrm{~cm}^{-1}$ correspond to backbone $-\mathrm{CH}_{2}$ - scissor and rocking motions.

\section{CONCLUSIONS}

In summary, several small peptides were derivatized by reaction with salicylaldehyde to create N-terminal imines (Schiff bases). The fragmentation patterns of the modified peptides, as generated by collision-induced dissociation, were then examined. The imine-modified peptides produced a more extensive series of $\mathrm{N}$-terminal $b$ and $a$ ions compared to the unmodified peptides and a reduction in intensity of the C-terminus containing $y$ ions. We attribute the latter observation to retention of the ionizing proton by the imine functional group of the $\mathrm{N}$-terminal ions following cleavage step in the oxazolone pathway presumed to be responsible for production of $b$ and $y$ ions.

Comparison of CID spectra from Sal-GGG, Sal-AGG and Sal-GGA revealed an additional pathway that involves elimination of the residue mass of the $\mathrm{N}$-terminal amino acid, despite the chemical modification to create the imine. This pathway was investigated further using infrared multiple-photon 
dissociation (IRMPD) spectroscopy and density functional theory (DFT) with Sal-AGG as the test peptide. The IRMPD spectrum for the product generated by loss of $71 \mathrm{u}$ matches one predicted by DFT for protonated Sal-GG, as well as the IRMPD spectrum of GG derivatized independently to produce a Schiff base. We conclude that the residue mass of the $\mathrm{N}$-terminal amino acid is eliminated through a pathway that involves nucleophilic attack by an amide $\mathrm{N}$ atom and possible formation an imidazole-4-one intermediate.

We also found that the IRMPD spectrum of $b_{2}{ }^{+}$is consistent with a structure that includes an oxazolone ring. The protonation site, however, is the imine $\mathrm{N}$ atom. This suggests either that the fragmentation pathway involves migration and transfer of an amide position proton, as has been observed previously for Nic-GGOMe, of that intramolecular proton transfer occurs after $b_{2}{ }^{+}$is generated from Sal-AGG. A clearer picture of the mechanism for generation of $b_{2}{ }^{+}$from the derivatized tripeptide should come with detailed study of the reaction energetics using DFT. Thus study is currently underway and will be the subject of a separate report.

It is clear from the CID spectra of Sal-VAAF and Sal-YGGFL that the pathway involving elimination of the residue mass of the $\mathrm{N}$-terminal residue becomes less competitive with increasing peptide size. This result is being investigated more comprehensively, along with the influence of the aldehyde used to create the imine and the identity of the N-terminal amino acid, using a larger group of model peptides. Also of interest is the multiple-stage CID of the imine-modified peptides, and the ability to identify peptide sequence directly in MSn experiments as has been reported for metal-cationized peptides.

\section{ACKNOWELDGEMENTS}

MJV acknowledges support for this work in the form of start-up funding from Duquesne University and the Bayer School of Natural and Environmental Sciences, and the National Science Foundation (CHE-0963450). The work of JKG was fully supported by the U.S. Department of Energy, Office of Basic Energy Sciences, Heavy Element Chemistry, at LBNL under Contract No. DE-AC0205CH11231. JO acknowledges the Netherlands Organisation for Scientific Research (NWO) for vici-grant no. 724.011.002 and the Stichting Physica. Construction and shipping of the FT-ICR-MS was made possible through funding from the National High Field FT-ICR Facility (grant CHE-9909502) at the National High Magnetic Field Laboratory, Tallahassee, FL. The excellent support by Dr. B. Redlich and others of the FELIX staff is gratefully acknowledged. 


\section{SUPPORTING INFORMATION}

CID spectra of underivatized GGG, AGG and GGA, and comparisons of IRMPD and theoretical spectra of structures II and IV for protonated Sal-AGG and structures V, VII, IX and X for the species created by loss of $71 \mathrm{u}$ from protonated Sal-AGG are provided in the supporting information. This data is available free of charge via the internet at http://www.sciencedirect.com 


\section{LITERATURE CITED}

(1) Aebersold, R.; Goodlett, D. R. Mass spectrometry in proteomics. Chem. Rev. 2001, 101, 269-295.

(2) Dancik, V.; Addona, T. A.; Clauser, K. R.; Vath, J. E.; Pevzner, P. A. De novo peptide sequencing via tandem mass spectrometry. J. Comp. Biol. 1999, 6, 327-342.

(3) Eng, J. K.; McCormack, A. L.; Yates, J. R. An approach to correlate tandem mass spectral data of peptides with amino acid sequences in a protein database. J. Am. Soc. Mass Spectrom. 1994, 5, 976-989.

(4) Griffin, T. J.; Goodlett, D. R.; Aebersold, R. Advances in proteome analysis by mass spectrometry. Curr. Opin. Biotech. 2001, 12, 607-612.

(5) Gucinski, A. C.; Dodds, E. D.; Li, W.; Wysocki, V. H. Understanding and exploiting Peptide fragment ion intensities using experimental and informatic approaches. Meth. Mol. Biol. 2010, 604, 7394.

(6) Hart, S. R.; Gaskell, S. J. Methods of proteome analysis: challenges and opportunities. SEB Exp. Biol. Ser. 2008, 61, 37-64.

(7) Huang, Y.; Tseng, G. C.; Yuan, S.; Pasa-Tolic, L.; Lipton, M. S.; Smith, R. D.; Wysocki, V. H. A data-mining scheme for identifying peptide structural motifs responsible for different MS/MS fragmentation intensity patterns. J. Proteome Res. 2008, 7, 70-79.

(8) Hunt, D. F.; Yates, J. R., 3rd; Shabanowitz, J.; Winston, S.; Hauer, C. R. Protein sequencing by tandem mass spectrometry. Proc. Nat. Acad. Sci. U. S. A. 1986, 83, 6233-6237.

(9) Steen, H.; Mann, M. The ABC's (and XYZ's) of peptide sequencing. Nature Rev. Mol. Cell Biol. 2004, 5, 699-711.

(10) Taylor, J. A.; Johnson, R. S. Sequence database searches via de novo peptide sequencing by tandem mass spectrometry. Rapid Comm. Mass Spectrom.1997, 11, 1067-1075.

(11) Taylor, J. A.; Johnson, R. S. Implementation and uses of automated de novo peptide sequencing by tandem mass spectrometry. Anal. Chem. 2001, 73, 2594-2604.

(12) Wysocki, V. H.; Resing, K. A.; Zhang, Q.; Cheng, G. Mass spectrometry of peptides and proteins. Methods 2005, 35, 211-222.

(13) Yates, J. R., 3rd; Eng, J. K.; McCormack, A. L.; Schieltz, D. Method to correlate tandem mass spectra of modified peptides to amino acid sequences in the protein database. Anal. Chem. 1995, $67,1426-1436$.

(14) Paizs, B.; Suhai, S. Fragmentation pathways of protonated peptides. Mass Spectrom. Rev. 2005, 24, 508-548.

(15) Harrison, A. G. To b or not to b: the ongoing saga of peptide b ions. Mass Spectrom. Rev. 2009, 28, 640-654.

(16) Papayannopoulos, I. A. The interpretation of collision-induced dissociation tandem mass spectra of peptides. Mass Spectrom. Rev. 1995, 14, 49-73.

(17) Roepstorff, P.; Fohlman, J. Proposal for a common nomenclature for sequence ions in mass spectra of peptides. Biomed. Mass Spectrom. 1984, 11, 601.

(18) Dongré, A. R.; Jones, J. L.; Somogyi, Á.; Wysocki, V. H. Influence of Peptide Composition, Gas-Phase Basicity, and Chemical Modification on Fragmentation Efficiency: Evidence for the Mobile Proton Model. J. Am. Chem. Soc. 1996, 118, 8365-8374.

(19) Wysocki, V. H.; Tsaprailis, G.; Smith, L. L.; Breci, L. A. Mobile and localized protons: a framework for understanding peptide dissociation. J. Mass Spectrom. 2000, 35, 1399-1406.

(20) Yalcin, T.; Khouw, C.; Csizmadia, I. G.; Peterson, M. R.; Harrison, A. G. Why Are B ions stable species in peptide spectra? J. Am. Soc. Mass Spectrom. 1995, 6, 1165-1174.

(21) Yalcin, T.; Csizmadia, I. G.; Peterson, M. R.; Harrison, A. G. The structure and fragmentation of $B n(n>/=3)$ ions in peptide spectra. J. Am. Soc. Mass Spectrom. 1996, 7, 233-242. 
(22) Csonka, I. P.; Paizs, B.; Lendvay, G.; Suhai, S. Proton mobility in protonated peptides: a joint molecular orbital and RRKM study. Rapid Comm. Mass Spectrom. 2000, 14, 417-431.

(23) Harrison, A. G.; Csizmadia, I. G.; Tang, T. H. Structure and fragmentation of b2 ions in peptide mass spectra. J. Am. Soc. Mass. Spectrom. 2000, 11, 427-436.

(24) Paizs, B.; Szlavik, Z.; Lendvay, G.; Vekey, K.; Suhai, S. Formation of a2+ ions of protonated peptides. An ab initio study. Rapid Comm. Mass Spectrom. 2000, 14, 746-755.

(25) Csonka, I. P.; Paizs, B.; Lendvay, G.; Suhai, S. Proton mobility and main fragmentation pathways of protonated lysylglycine. Rapid Comm. Mass Spectrom. 2001, 15, 1457-1472.

(26) Paizs, B.; Csonka, I. P.; Lendvay, G.; Suhai, S. Proton mobility in protonated glycylglycine and $\mathrm{N}$-formylglycylglycinamide: a combined quantum chemical and RKKM study. Rapid Comm. Mass Spectrom. 2001, 15, 637-650.

(27) Paizs, B.; Suhai, S. Theoretical study of the main fragmentation pathways for protonated glycylglycine. Rapid Comm. Mass Spectrom. 2001, 15, 651-663.

(28) Paizs, B.; Suhai, S. Combined quantum chemical and RRKM modeling of the main fragmentation pathways of protonated GGG. II. Formation of $b(2), y(1)$, and $y(2)$ ions. Rapid Comm. Mass Spectrom. 2002, 16, 375-389.

(29) Vaisar, T. U., J. Low-energy Collision Induced Dissociation of Protonated Peptides. Importance of an Oxazolone Formation for a Peptide Bond Cleavage. Eur. Mass Spectrom. 1998, 4, 359364.

(30) Polfer, N. C.; Oomens, J.; Suhai, S.; Paizs, B. Spectroscopic and theoretical evidence for oxazolone ring formation in collision-induced dissociation of peptides. J. Am. Chem. Soc. 2005, 127, 17154-17155.

(31) Yoon, S. H.; Chamot-Rooke, J.; Perkins, B. R.; Hilderbrand, A. E.; Poutsma, J. C.; Wysocki, V. H. IRMPD spectroscopy shows that AGG forms an oxazolone $b_{2+}$ ion. J. Am. Chem. Soc. 2008, 130, 17644-17645.

(32) Oomens, J.; Young, S.; Molesworth, S.; van Stipdonk, M. Spectroscopic evidence for an oxazolone structure of the $b_{2}$ fragment ion from protonated tri-alanine. J. Am. Soc. Mass Spectrom. 2009, 20, 334-339.

(33) Sinha, R.; Erlekam, U.; Bythell, B.; Paizs, B.; Maître, P. Diagnosing the Protonation Site of b 2 Peptide Fragment lons using IRMPD in the $\mathrm{X}-\mathrm{H}(\mathrm{X}=\mathrm{O}, \mathrm{N}$, and $\mathrm{C})$ Stretching Region. J. Am. Soc. Mass Spectrom. 2011, 22, 1645-1650.

(34) Wang, D.; Gulyuz, K.; Stedwell, C. N.; Polfer, N. C. Diagnostic NH and OH vibrations for oxazolone and diketopiperazine structures: b2 from protonated triglycine. J. Am. Soc. Mass Spectrom. 2011, 22, 1197-1203.

(35) Harrison, A. G.; Young, A. B.; Bleiholder, C.; Suhai, S.; Paizs, B. Scrambling of sequence information in collision-induced dissociation of peptides. J. Am. Chem. Soc. 2006, 128, 10364-10365.

(36) Jia, C.; Qi, W.; He, Z. Cyclization reaction of peptide fragment ions during multistage collisionally activated decomposition: an inducement to lose internal amino-acid residues. J. Am. Soc. Mass Spectrom. 2007, 18, 663-678.

(37) Bleiholder, C.; Osburn, S.; Williams, T. D.; Suhai, S.; Van Stipdonk, M.; Harrison, A. G.; Paizs, B. Sequence-scrambling fragmentation pathways of protonated peptides. J. Am. Chem. Soc. 2008, 130, 17774-17789.

(38) Harrison, A. G. Peptide sequence scrambling through cyclization of b(5) ions. J. Am. Soc. Mass Spectrom. 2008, 19, 1776-1780.

(39) Polfer, N. C.; Bohrer, B. C.; Plasencia, M. D.; Paizs, B.; Clemmer, D. E. On the dynamics of fragment isomerization in collision-induced dissociation of peptides. J. Phys. Chem. A 2008, 112, 12861293. 
(40) Erlekam, U.; Bythell, B. J.; Scuderi, D.; Van Stipdonk, M.; Paizs, B.; Maitre, P. Infrared spectroscopy of fragments of protonated peptides: direct evidence for macrocyclic structures of $b_{5}$ ions. J. Am. Chem. Soc. 2009, 131, 11503-11508.

(41) Harrison, A. G. Cyclization of peptide $b_{9}$ ions. J. Am. Soc. Mass Spectrom. 2009, 20, 2248-

2253.

(42) Molesworth, S.; Osburn, S.; Van Stipdonk, M. Influence of size on apparent scrambling of sequence during CID of b-type ions. J. Am. Soc. Mass Spectrom. 2009, 20, 2174-2181.

(43) Bythell, B. J.; Knapp-Mohammady, M.; Paizs, B.; Harrison, A. G. Effect of the His residue on the cyclization of b ions. J. Am. Soc. Mass Spectrom. 2010, 21, 1352-1363.

(44) Fattahi, A.; Zekavat, B.; Solouki, T. H/D exchange kinetics: experimental evidence for formation of different $b$ fragment ion conformers/isomers during the gas-phase peptide sequencing. $J$. Am. Soc. Mass Spectrom. 2010, 21, 358-369.

(45) Atik, A. E.; Yalcin, T. A systematic study of acidic peptides for b-type sequence scrambling. J. Am. Soc. Mass Spectrom. 2011, 22, 38-48.

(46) Li, X.; Huang, Y.; O'Connor, P. B.; Lin, C. Structural heterogeneity of doubly-charged peptide b-ions. J. Am. Soc. Mass Spectrom. 2011, 22, 245-254.

(47) Dong, N. P.; Liang, Y. Z.; Yi, L. Z. Investigation of scrambled ions in tandem mass spectra. Part 1. Statistical characterization. J. Am. Soc. Mass Spectrom. 2012, 23, 1209-1220.

(48) Tirado, M.; Polfer, N. C. Defying entropy: forming large head-to-tail macrocycles in the gas phase. Angew. Chem., Int. Ed. 2012, 51, 6436-6438.

(49) Dong, N. P.; Liang, Y. Z.; Yi, L. Z.; Lu, H. M. Investigation of scrambled ions in tandem mass spectra, part 2. On the influence of the ions on peptide identification. J. Am. Soc. Mass Spectrom. 2013, 24, 857-867.

(50) Harrison, A. G.; Tasoglu, C.; Yalcin, T. Non-direct sequence ions in the tandem mass spectrometry of protonated peptide amides--an energy-resolved study. J. Am. Soc. Mass Spectrom. 2013, 24, 1565-1572.

(51) Miladi, M.; Harper, B.; Solouki, T. Evidence for sequence scrambling in collision-induced dissociation of y-type fragment ions. J. Am. Soc. Mass Spectrom. 2013, 24, 1755-1766.

(52) Zekavat, B.; Miladi, M.; Becker, C.; Munisamy, S. M.; Solouki, T. Combined use of postion mobility/collision-induced dissociation and chemometrics for $\mathrm{b}$ fragment ion analysis. J. Am. Soc. Mass Spectrom. 2013, 24, 1355-1365.

(53) Chawner, R.; Holman, S. W.; Gaskell, S. J.; Eyers, C. E. Peptide Scrambling During Collision-Induced Dissociation is Influenced by N-terminal Residue Basicity. J. Am. Soc. Mass Spectrom. 2014, 25, 1927-1938.

(54) Harper, B.; Miladi, M.; Solouki, T. Loss of internal backbone carbonyls: additional evidence for sequence-scrambling in collision-induced dissociation of y-type ions. J. Am. Soc. Mass Spectrom. 2014, 25, 1716-1729.

(55) Harrison, A. G. Effect of the sarcosine residue on sequence scrambling in peptide $b(5)$ ions. J. Mass Spectrom. 2014, 49, 161-167.

(56) Jia, C.; Wu, Z.; Lietz, C. B.; Liang, Z.; Cui, Q.; Li, L. Gas-phase ion isomer analysis reveals the mechanism of peptide sequence scrambling. Anal. Chem. 2014, 86, 2917-2924.

(57) Zekavat, B.; Miladi, M.; Al-Fdeilat, A. H.; Somogyi, A.; Solouki, T. Evidence for sequence scrambling and divergent $H / D$ exchange reactions of doubly-charged isobaric b-type fragment ions. $J$. Am. Soc. Mass Spectrom. 2014, 25, 226-236.

(58) Chen, X.; Yu, L.; Steill, J. D.; Oomens, J.; Polfer, N. C. Effect of peptide fragment size on the propensity of cyclization in collision-induced dissociation: oligoglycine $b_{2}-b_{8}$. J. Am. Chem. Soc. 2009, $131,18272-18282$. 
(59) Saminathan, I. S.; Wang, X. S.; Guo, Y.; Krakovska, O.; Voisin, S.; Hopkinson, A. C.; Siu, K. $\mathrm{W}$. The extent and effects of peptide sequence scrambling via formation of macrocyclic $B$ ions in model proteins. J. Am. Soc. Mass Spectrom. 2010, 21, 2085-2094.

(60) Goloborodko, A. A.; Gorshkov, M. V.; Good, D. M.; Zubarev, R. A. Sequence scrambling in shotgun proteomics is negligible. J. Am. Soc. Mass Spectrom. 2011, 22, 1121-1124.

(61) Yu, L.; Tan, Y.; Tsai, Y.; Goodlett, D. R.; Polfer, N. C. On the relevance of peptide sequence permutations in shotgun proteomics studies. J. Proteome Res. 2011, 10, 2409-2416.

(62) Olsen, J. V.; Mann, M. Improved peptide identification in proteomics by two consecutive stages of mass spectrometric fragmentation. Proc. Nat. Acad. Sci. U. S. A. 2004, 101, 13417-13422.

(63) Samgina, T. Y.; Kovalev, S. V.; Gorshkov, V. A.; Artemenko, K. A.; Poljakov, N. B.; Lebedev, A. T. N-terminal tagging strategy for de novo sequencing of short peptides by ESI-MS/MS and MALDI-MS/MS. J. Am. Soc. Mass Spectrom. 2010, 21, 104-111.

(64) Valle, J. J.; Eyler, J. R.; Oomens, J.; Moore, D. T.; van der Meer, A. F. G.; von Helden, G.; Meijer, G.; Hendrickson, C. L.; Marshall, A. G.; Blakney, G. T. Free electron laser-Fourier transform ion cyclotron resonance mass spectrometry facility for obtaining infrared multiphoton dissociation spectra of gaseous ions. Rev. Sci. Instrum. 2005, 76, 023103.

(65) Bagratashvili, V. N. L., V. S.; Makarov, A. A; Ryabov, E.A. . Multiple Photon Infrared Laser Photophysics and Photochemistry. Harwood, Chur: Switzerland 1985.

(66) Moore, D. T.; Oomens, J.; Eyler, J. R.; von Helden, G.; Meijer, G.; Dunbar, R. C. Infrared Spectroscopy of Gas-Phase $\mathrm{Cr}^{+}$Coordination Complexes: Determination of Binding Sites and Electronic States. J. Am. Chem. Soc. 2005, 127, 7243-7254.

(67) Oomens, J. T., A. G. G. M.; Sartakov, B. G.; von Helden, G.; Meijer, G. Laboratory Infrared Spectroscopy of Cationic Polycyclic Aromatic Hydrocarbon Molecules. Astrophys. J. 2003, 591, 968-985.

(68) Frisch, M. J.; Trucks, G. W.; Schlegel, H. B.; Scuseria, G. E.; Robb, M. A.; Cheeseman, J. R.; Scalmani, G.; Barone, V.; Mennucci, B.; Petersson, G. A.; Nakatsuji, H.; Caricato, M.; Li, X.; Hratchian, H. P.; Izmaylov, A. F.; Bloino, J.; Zheng, G.; Sonnenberg, J. L.; Hada, M.; Ehara, M.; Toyota, K.; Fukuda, R.; Hasegawa, J.; Ishida, M.; Nakajima, T.; Honda, Y.; Kitao, O.; Nakai, H.; Vreven, T.; Montgomery Jr., J. A.; Peralta, J. E.; Ogliaro, F.; Bearpark, M. J.; Heyd, J.; Brothers, E. N.; Kudin, K. N.; Staroverov, V. N.; Kobayashi, R.; Normand, J.; Raghavachari, K.; Rendell, A. P.; Burant, J. C.; Iyengar, S. S.; Tomasi, J.; Cossi, M.; Rega, N.; Millam, N. J.; Klene, M.; Knox, J. E.; Cross, J. B.; Bakken, V.; Adamo, C.; Jaramillo, J.; Gomperts, R.; Stratmann, R. E.; Yazyev, O.; Austin, A. J.; Cammi, R.; Pomelli, C.; Ochterski, J. W.; Martin, R. L.; Morokuma, K.; Zakrzewski, V. G.; Voth, G. A.; Salvador, P.; Dannenberg, J. J.; Dapprich, S.; Daniels, A. D.; Farkas, Ö.; Foresman, J. B.; Ortiz, J. V.; Cioslowski, J.; Fox, D. J.: Gaussian 09. Gaussian, Inc.: Wallingford, CT, USA, 2009.

(69) Molesworth, S.; Leavitt, C. M.; Groenewold, G. S.; Oomens, J.; Steill, J. D.; van Stipdonk, M. Spectroscopic evidence for mobilization of amide position protons during CID of model peptide ions. J. Am. Soc. Mass Spectrom. 2009, 20, 1841-1845.

(70) Bythell, B. J.; Erlekam, U.; Paizs, B.; Maître, P. Infrared Spectroscopy of Fragments from Doubly Protonated Tryptic Peptides. ChemPhysChem 2009, 10, 883-885.

(71) Bythell, B. J.; Dain, R. P.; Curtice, S. S.; Oomens, J.; Steill, J. D.; Groenewold, G. S.; Paizs, B.; Van Stipdonk, M. J. Structure of $\left[\mathrm{M}+\mathrm{H}-\mathrm{H}_{2} \mathrm{O}\right]^{+}$from protonated tetraglycine revealed by tandem mass spectrometry and IRMPD spectroscopy. J. Phys. Chem. A 2010, 114, 5076-5082.

(72) Verkerk, U. H.; Zhao, J.; Van Stipdonk, M. J.; Bythell, B. J.; Oomens, J.; Hopkinson, A. C.; Siu, K. W. Structure of the $\left[\mathrm{M}+\mathrm{H}-\mathrm{H}_{2} \mathrm{O}\right]^{+}$ion from tetraglycine: a revisit by means of density functional theory and isotope labeling. J. Phys. Chem. A 2011, 115, 6683-6687.

(73) Lau, J. K.-C.; Zhao, J.; Siu, K. W. M.; Hopkinson, A. C. Elimination of water from the backbone of protonated tetraglycine. Int. J. Mass Spectrom. 2012, 316-318, 268-272. 
(74) Bythell, B. J.; Barofsky, D. F.; Pingitore, F.; Polce, M. J.; Wang, P.; Wesdemiotis, C.; Paizs, B. Backbone cleavages and sequential loss of carbon monoxide and ammonia from protonated AGG: a combined tandem mass spectrometry, isotope labeling, and theoretical study. J. Am. Soc. Mass Spectrom. 2007, 18, 1291-1303.

(75) She, Y.-M.; Krokhin, O.; Spicer, V.; Loboda, A.; Garland, G.; Ens, W.; Standing, K.; Westmore, J. Formation of $\left(b_{n-1}+\mathrm{H}_{2} \mathrm{O}\right)$ ions by collisional activation of maldi-formed peptide $[\mathrm{M}+\mathrm{H}]+$ ions in a QqTOF mass spectrometer. J. Am. Soc. Mass Spectrom. 2007, 18, 1024-1037.

(76) Hiserodt, R. D.; Brown, S. M.; Swijter, D. F. H.; Hawkins, N.; Mussinan, C. J. A Study of $\mathrm{b}_{1}+\mathrm{H} 2 \mathrm{O}$ and $\mathrm{b}_{1}$-lons in the Product Ion Spectra of Dipeptides Containing N-Terminal Basic Amino Acid Residues. J. Am. Soc. Mass Spectrom. 2007, 18, 1414-1422.

(77) Bythell, B. J.; Csonka, I. P.; Suhai, S.; Barofsky, D. F.; Paizs, B. Gas-phase structure and fragmentation pathways of singly protonated peptides with $\mathrm{N}$-terminal arginine. J. Phys. Chem. B 2010, $114,15092-15105$.

(78) Grese, R. P.; Cerny, R. L.; Gross, M. L. Metal ion-peptide interactions in the gas phase: a tandem mass spectrometry study of alkali metal cationized peptides. J. Am. Chem. Soc. 1989, 111, 28352842.

(79) Teesch, L. M.; Adams, J. Fragmentations of gas-phase complexes between alkali metal ions and peptides: metal ion binding to carbonyl oxygens and other neutral functional groups. J. Am. Chem. Soc. 1991, 113, 812-820.

(80) Teesch, L. M.; Orlando, R. C.; Adams, J. Location of the alkali metal ion in gas-phase peptide complexes. J. Am. Chem. Soc. 1991, 113, 3668-3675.

(81) Lee, V. W. M.; Li, H.; Lau, T.-C.; Siu, K. W. M. Structures of $b$ and a Product lons from the Fragmentation of Argentinated Peptides. J. Am. Chem. Soc. 1998, 120, 7302-7309.

(82) Lin, T.; Glish, G. L. C-Terminal Peptide Sequencing via Multistage Mass Spectrometry. Anal. Chem. 1998, 70, 5162-5165.

(83) Chu, I. K.; Guo, X.; Lau, T.-C.; Siu, K. W. M. Sequencing of Argentinated Peptides by Means of Electrospray Tandem Mass Spectrometry. Anal. Chem. 1999, 71, 2364-2372.

(84) Chu, I.; Shoeib, T.; Guo, X.; Rodriquez, C.; Lau, T.-C.; Hopkinson, A.; Siu, K. W. M. Characterization of the product ions from the collision-induced dissociation of argentinated peptides. $J$. Am. Soc. Mass Spectrom. 2001, 12, 163-175.

(85) Lin, T.; Payne, A.; Glish, G. Dissociation pathways of alkali-cationized peptides: Opportunities for C-terminal peptide sequencing. J. Am. Soc. Mass Spectrom. 2001, 12, 497-504.

(86) Anbalagan, V.; Perera, B. A.; Silva, A. T. M.; Gallardo, A. L.; Barber, M.; Barr, J. M.; Terkarli, S. M.; Talaty, E. R.; Van Stipdonk, M. J. Formation of $\left[b_{n}+17+A g\right]^{+}$product ions from Ag+ cationized native and acetylated peptides. J. Mass Spectrom. 2002, 37, 910-926.

(87) Barr, J. M.; Van Stipdonk, M. J. Multi-stage tandem mass spectrometry of metal cationized leucine enkephalin and leucine enkephalin amide. Rapid Comm. Mass Spectrom. 2002, 16, 566-578.

(88) Bythell, B. J.; Suhai, S.; Somogyi, A.; Paizs, B. Proton-driven amide bond-cleavage pathways of gas-phase peptide ions lacking mobile protons. J. Am. Chem. Soc. 2009, 131, 14057-14065.

(89) Feng, W. Y.; Gronert, S.; Fletcher, K. A.; Warres, A.; Lebrilla, C. B. The mechanism of Cterminal fragmentations in alkali metal ion complexes of peptides. Int. J. Mass Spectrom. 2003, 222, 117134.

(90) Bythell, B. J.; Molesworth, S.; Osburn, S.; Cooper, T.; Paizs, B.; Van Stipdonk, M. Structure and reactivity of $a(n)$ and $a(n)$ peptide fragments investigated using isotope labeling, tandem mass spectrometry, and density functional theory calculations. J. Am. Soc. Mass Spectrom. 2008, 19, 1788-1798. 
(91) Sztaray, J.; Memboeuf, A.; Drahos, L.; Vekey, K. Leucine enkephalin--a mass spectrometry standard. Mass Spectrom. Rev. 2011, 30, 298-320.

(92) Polfer, N. C.; Oomens, J.; Suhai, S.; Paizs, B. Infrared spectroscopy and theoretical studies on gas-phase protonated leu-enkephalin and its fragments: direct experimental evidence for the mobile proton. J. Am. Chem. Soc. 2007, 129, 5887-5897.

(93) Vachet, R. W.; Bishop, B. M.; Erickson, B. W.; Glish, G. L. Novel Peptide Dissociation: Gas-Phase Intramolecular Rearrangement of Internal Amino Acid Residues. J. Am. Chem. Soc. 1997, 119, 5481-5488.

(94) Tabb, D. L.; Huang, Y.; Wysocki, V. H.; Yates, J. R., 3rd. Influence of basic residue content on fragment ion peak intensities in low-energy collision-induced dissociation spectra of peptides. Anal. Chem. 2004, 76, 1243-1248. 


\section{LIST OF SCHEMES, FIGURES AND TABLES}

Scheme 1. Condensation reaction to convert peptide to N-terminal imine.

Scheme 2. Formation of $\mathrm{b}_{2}{ }^{+}$from Sal-GGG via oxazolone pathway (pathway a) and of $\left(\mathrm{b}_{2}+\mathrm{H}_{2} \mathrm{O}\right)$ by anhydride pathway (pathway b).

Scheme 3. Loss of N-terminal residue mass through ketopiperazine intermediate (pathway c) and imidazol-one intermediate (pathway d).

Figure 1. CID spectra of (a) Sal-GGG, (b) Sal-AGG and (c) Sal-GGA.

Figure 2. $\quad$ CID spectra of (a) VAAF and (b) Sal-VAAF.

Figure 3. CID spectra of (a) YGGFL and (b) Sal-YGGFL. Asterisks denote product ions generated through "sequence scrambling" pathways.

Figure $4 . \quad$ Lowest energy structures predicted by DFT for protonated Sal-AGG.

Figure 5. (a) IRMPD spectrum of protonated Sal-AGG compared to predicted spectra for lowest energy (b) imine N-protonated (structure I) and (c) amide-O protonated (structure III) structures for protonated Sal-AGG. The IRMPD spectrum from (a) is included as a grey trace in (b) and (c) to assist comparison.

Figure 6. Minima identified as possible structures for species created by elimination of $71 \mathrm{u}$ (residue mass of N-terminal amino acid), structures V, VI, VII, VIII, IX and $\mathbf{X}$, and $b_{2}{ }^{+}$, structures XI, XII and XIII, from protonated Sal-AGG.

Figure 7. (a) IRMPD spectrum of species generated by loss of $71 \mathrm{u}$ from protonated Sal-AGG compared to predicted spectra for lowest energy structures formed by (b) ketopiperazine pathway (structure VI) and (c) imidizol-one pathway (structure VIII). Spectrum in (d) is the IRMPD spectrum of protonated Sal-GG. The IRMPD spectrum from (a) is included as a grey trace in $(b)-(d)$ to assist comparison.

Figure 8. (a) IRMPD spectrum of species of $\mathrm{b}_{2}{ }^{+}$from protonated Sal-AGG compared to predicted spectra for lowest energy structures (b) XI, (c) XII and (d) XIII. The IRMPD spectrum from (a) is included as a grey trace in (b)-(d) to assist comparison.

Table 1. Electronic energies, zero-point energies and relative energies of minima identified for Sal-AGG, candidate products formed by elimination of residue mass of N-terminal amino acid and for $b_{2}{ }^{+}$. 


\section{Scheme 1.}

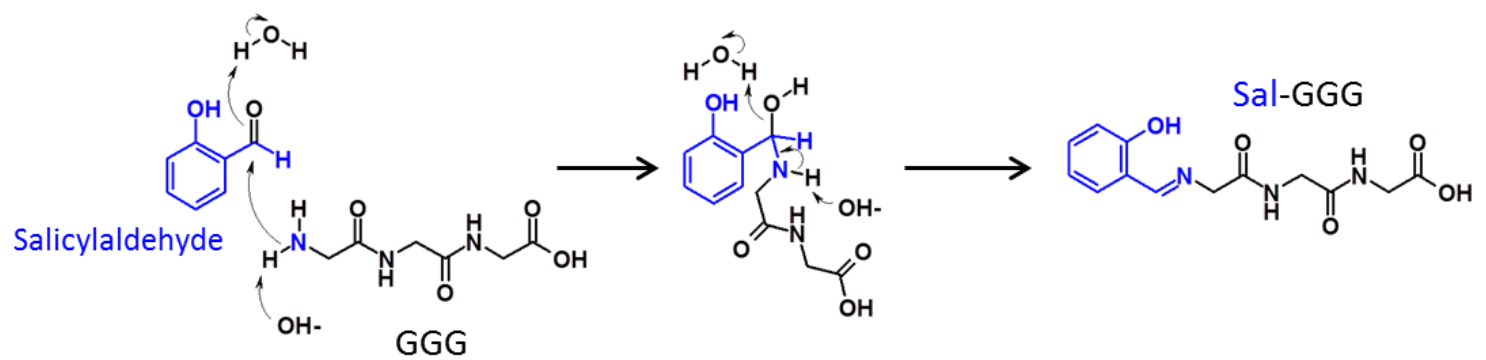

Scheme 2.

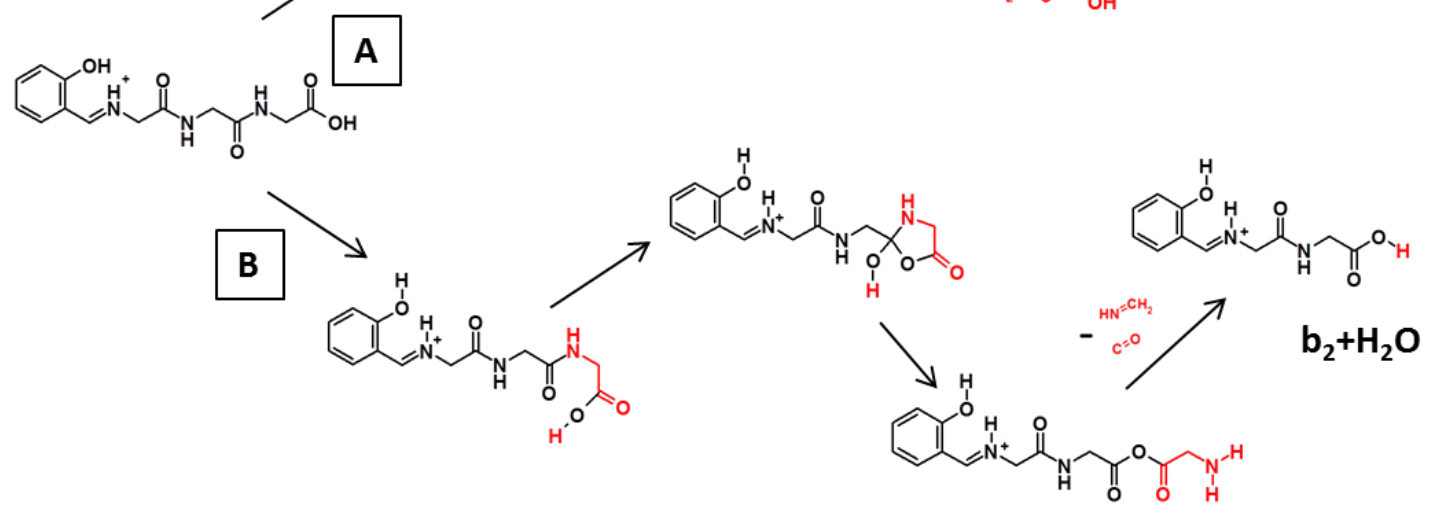

Scheme 3.
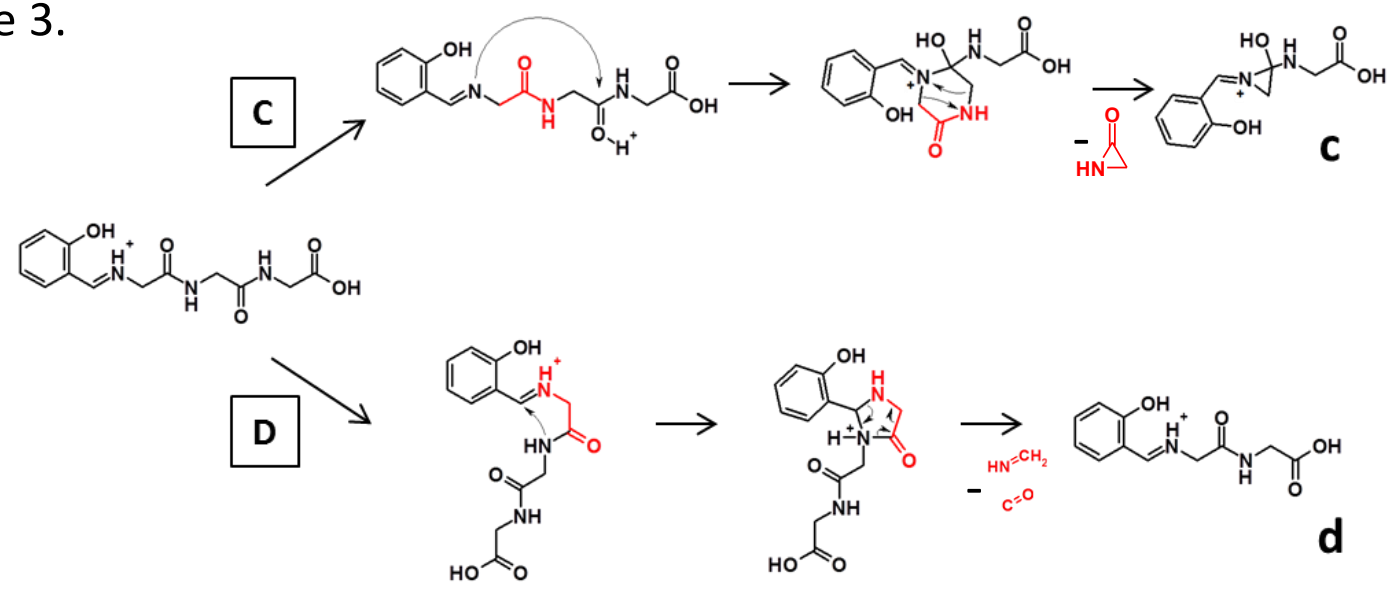

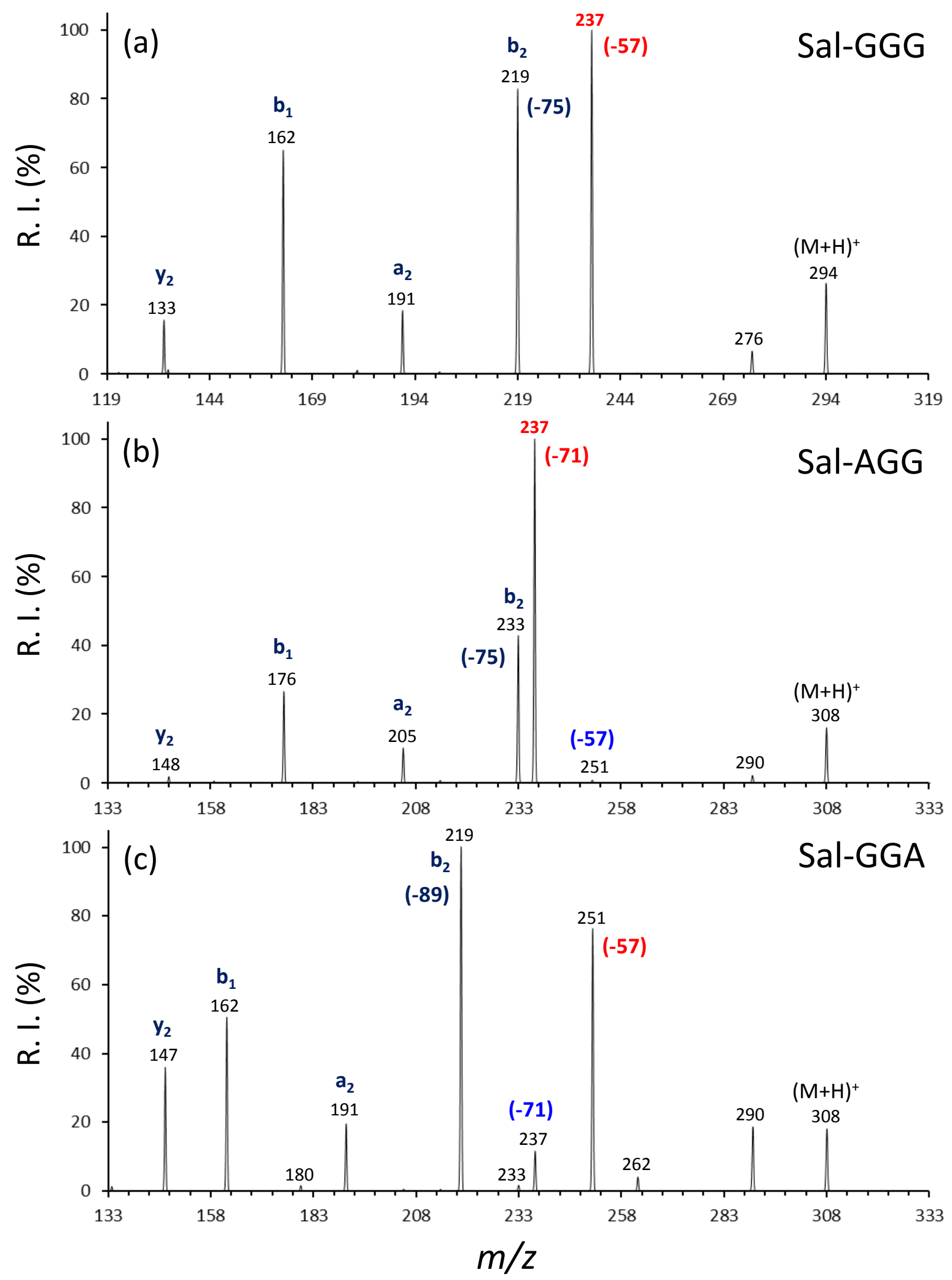

Figure 1. 


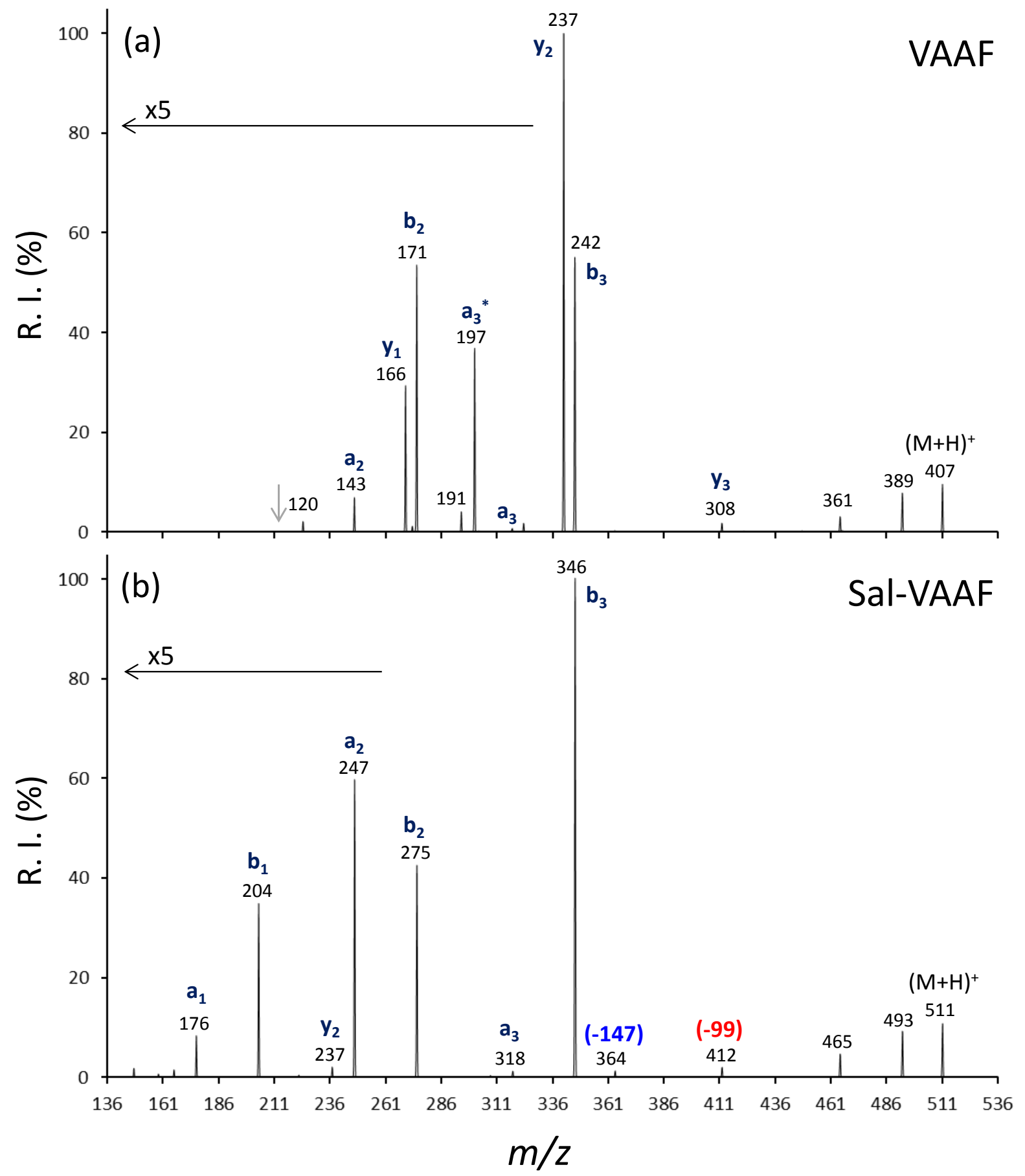

Figure 2. 


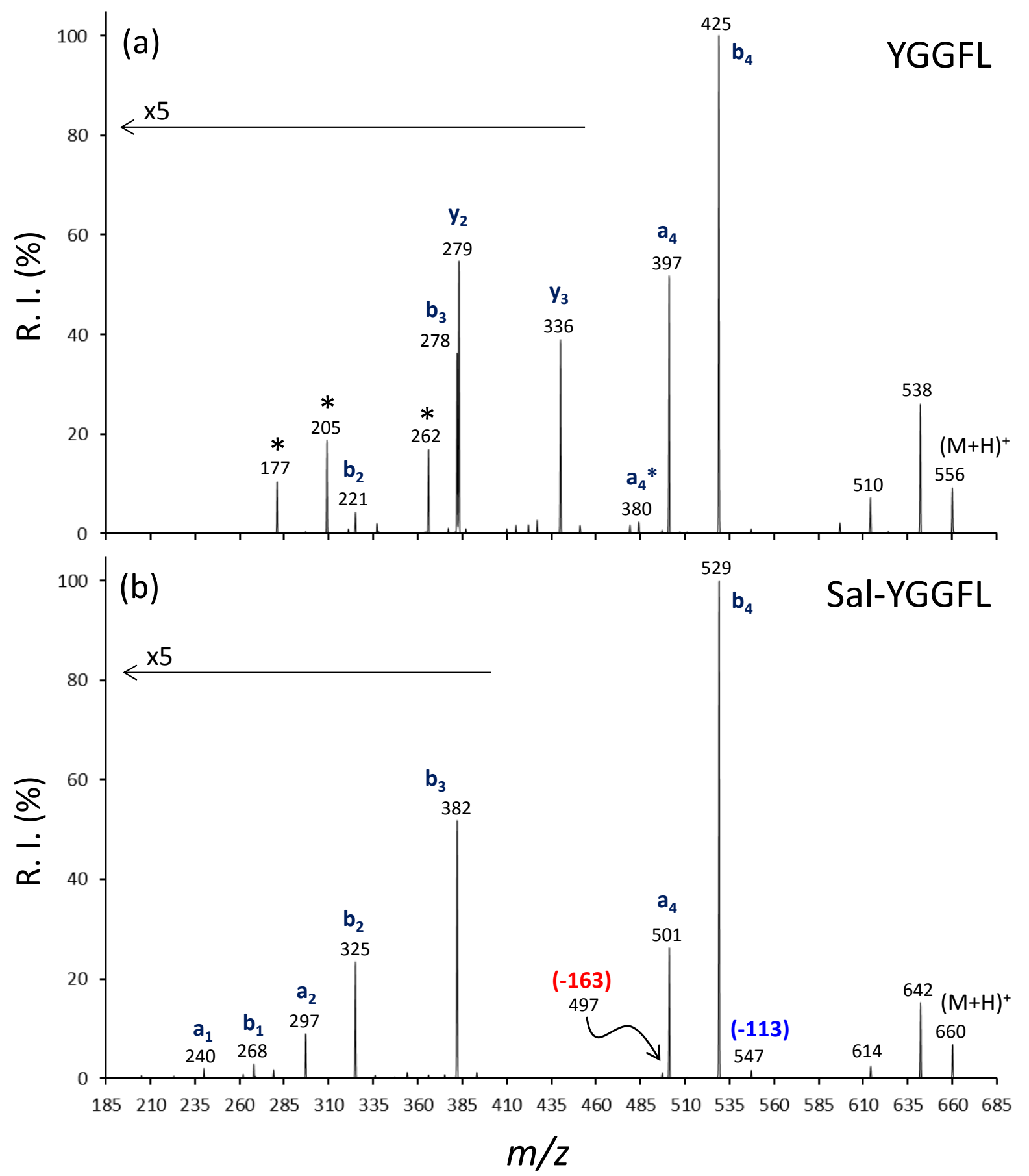

Figure 3. 

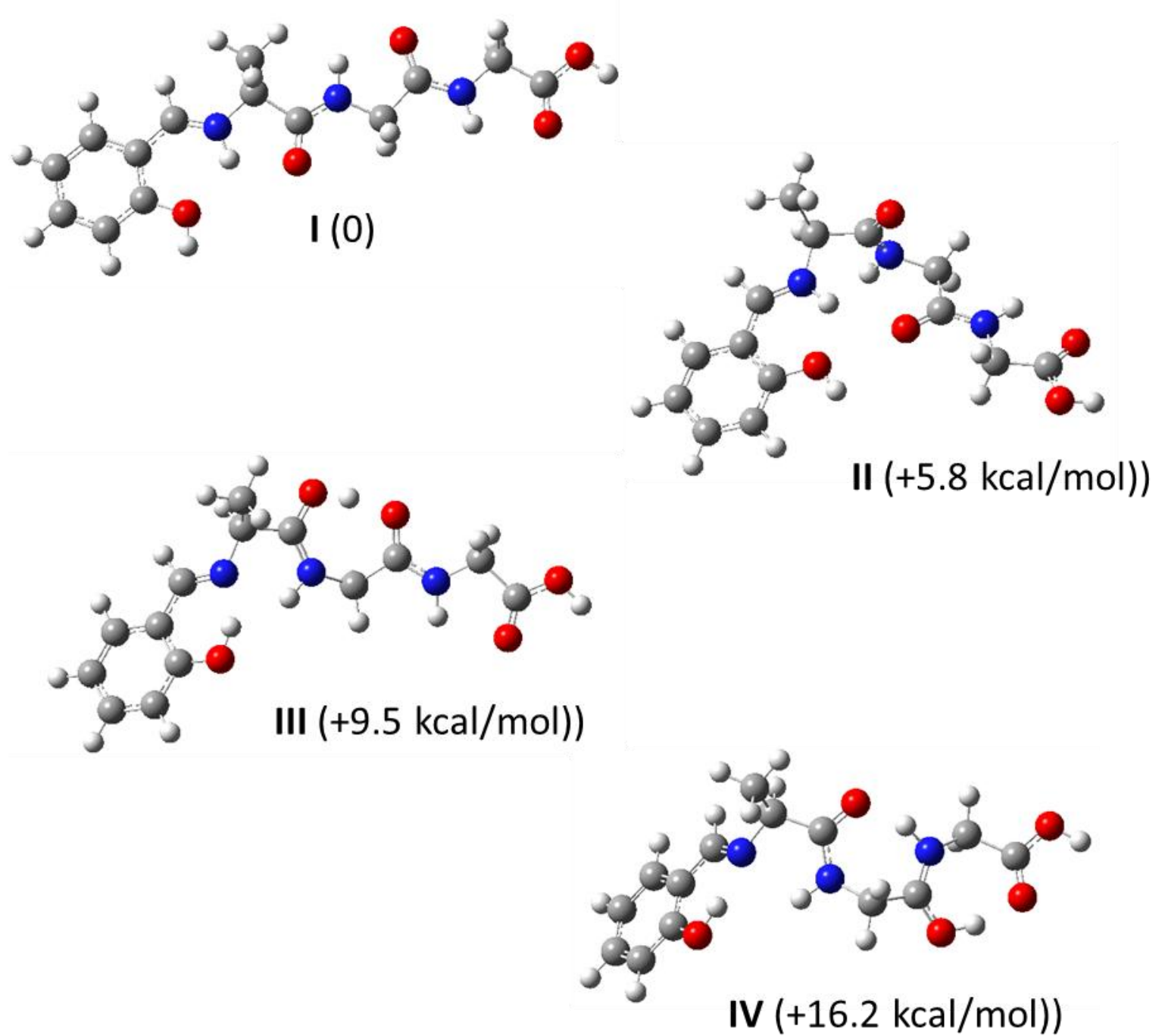

Figure 4 . 


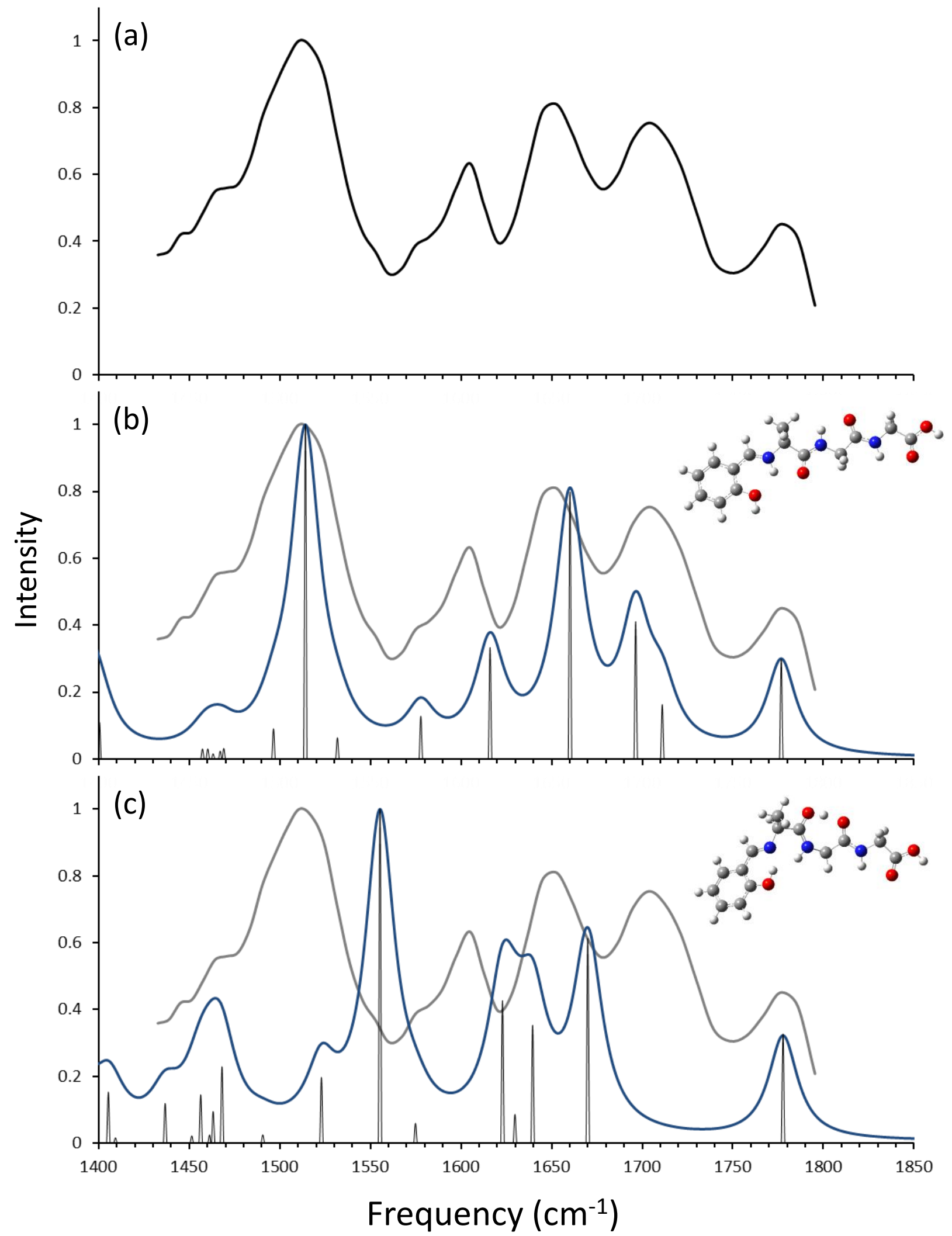

Figure 5. 

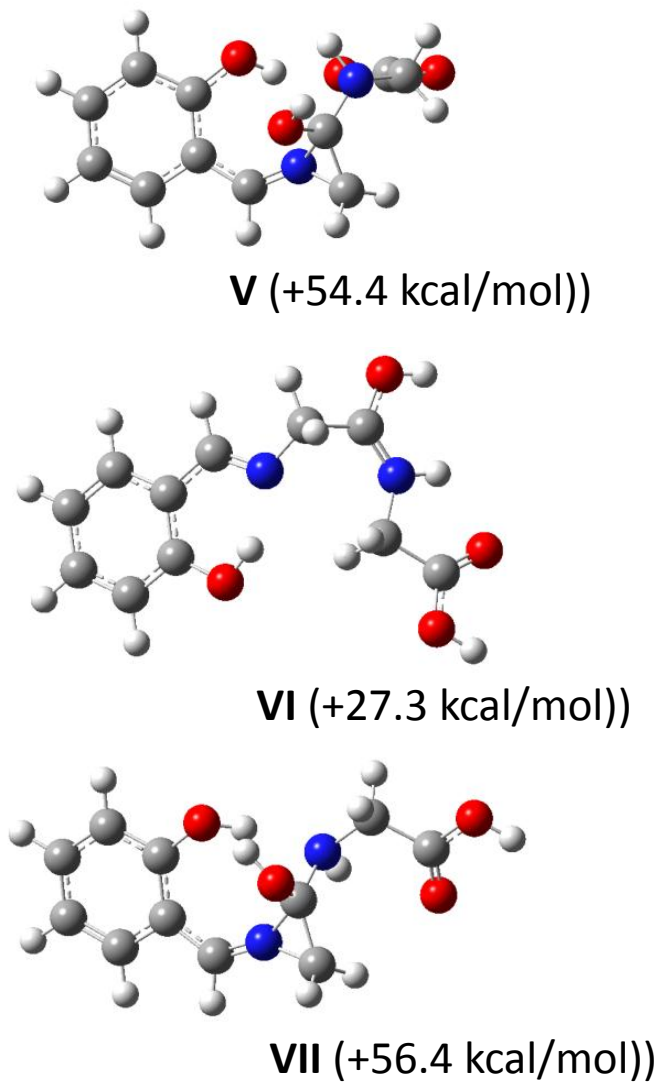
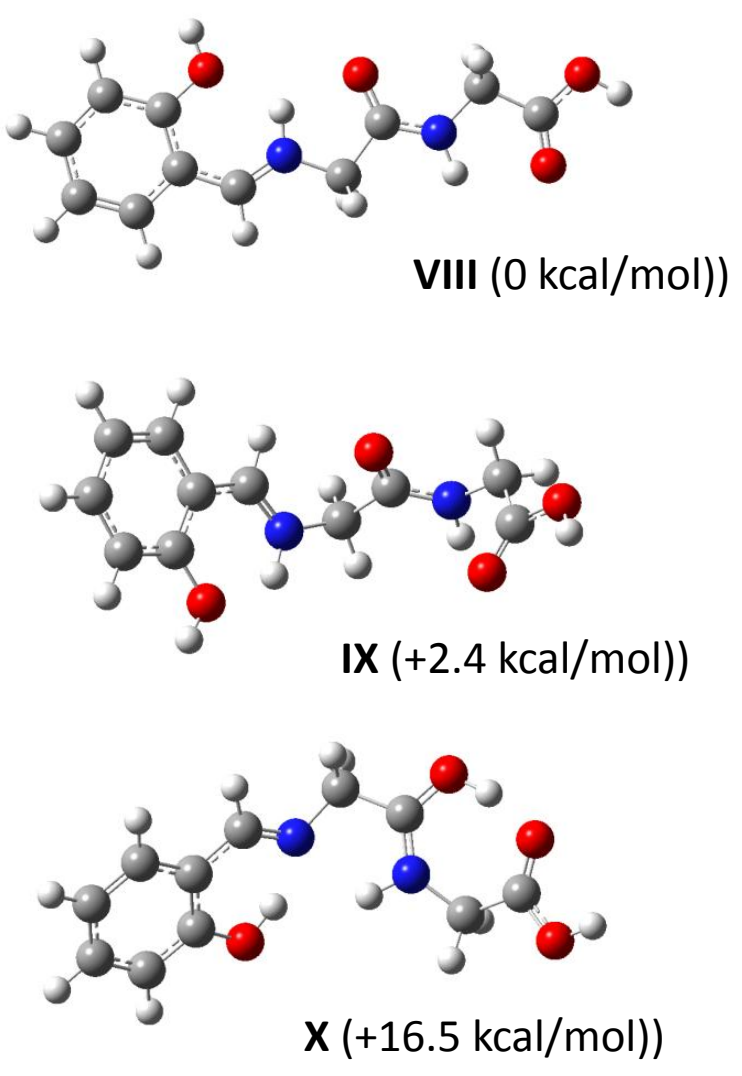

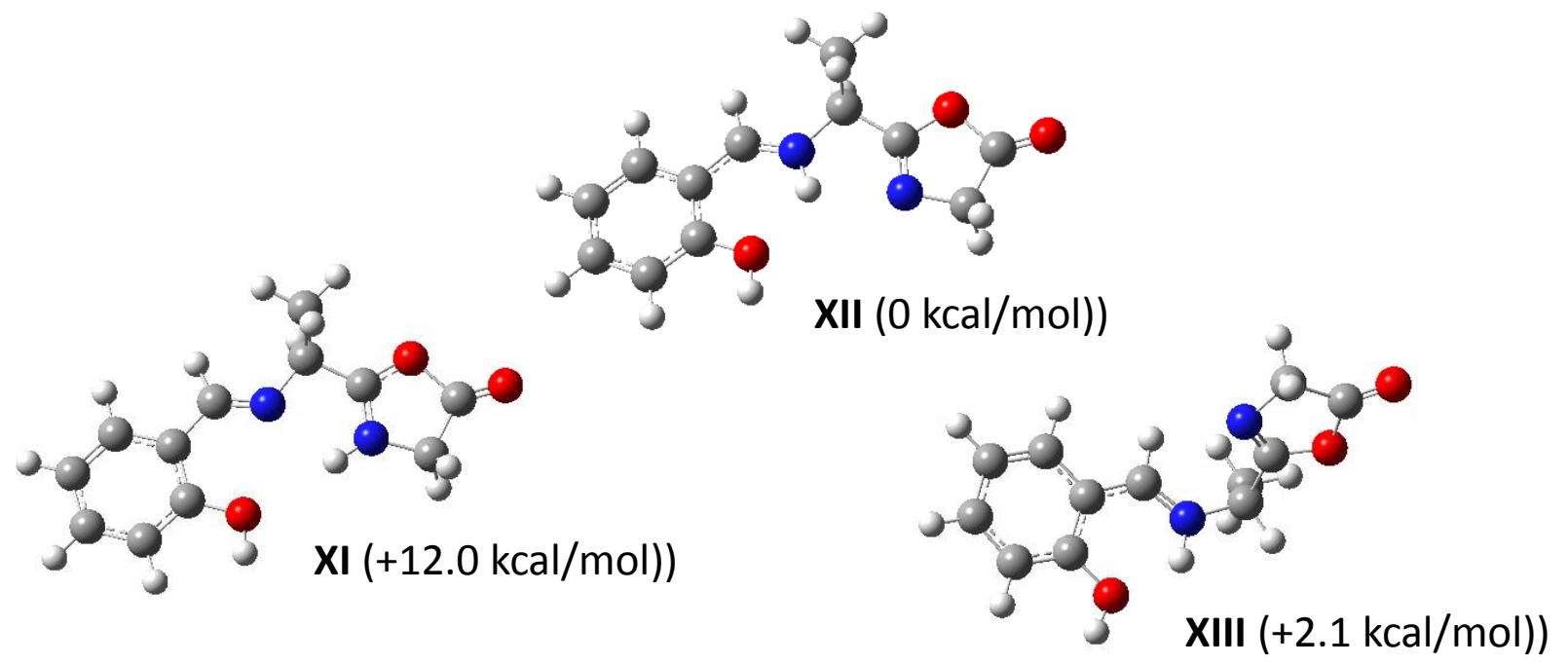

Figure 6. 


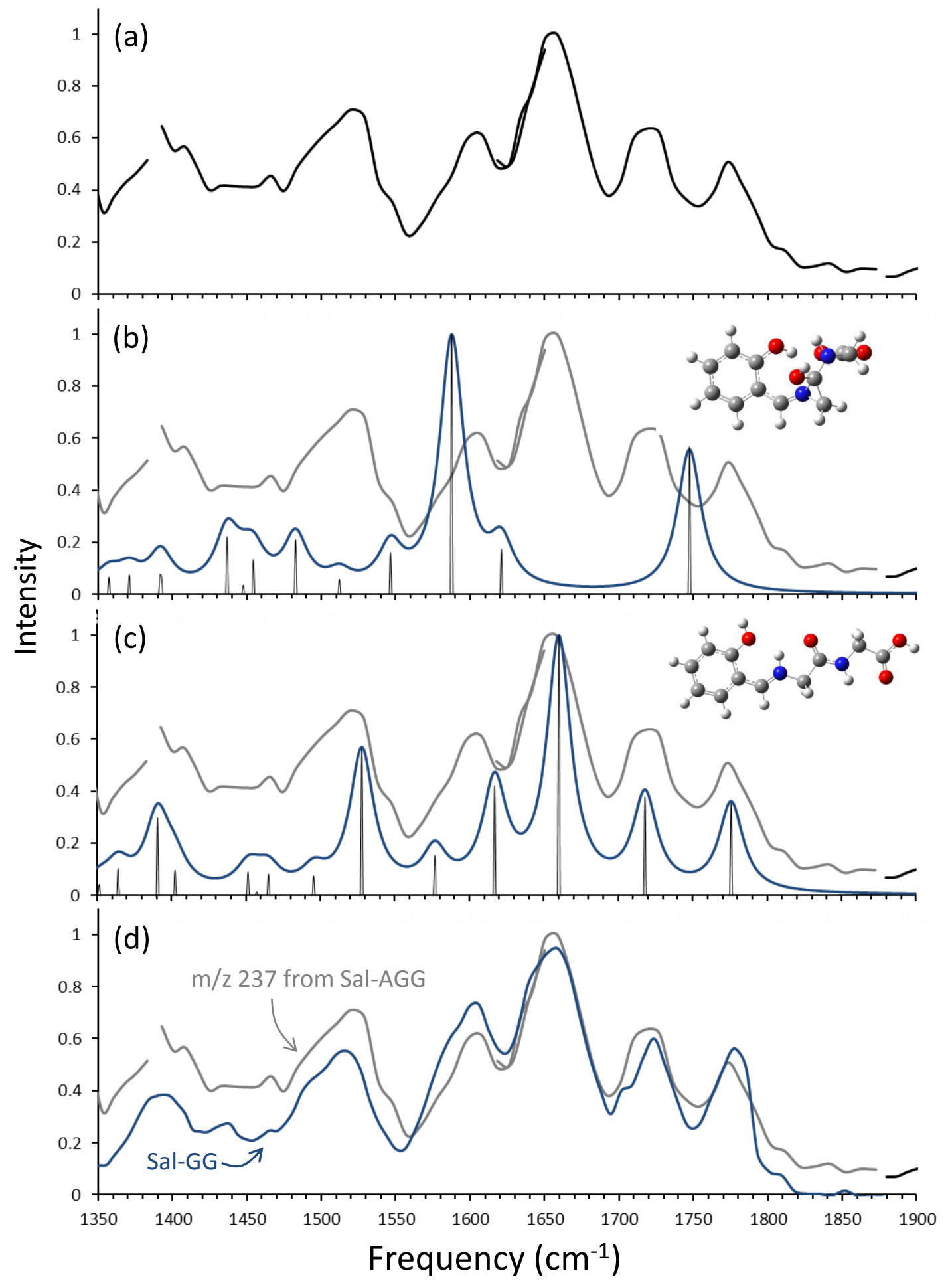

Figure 7. 


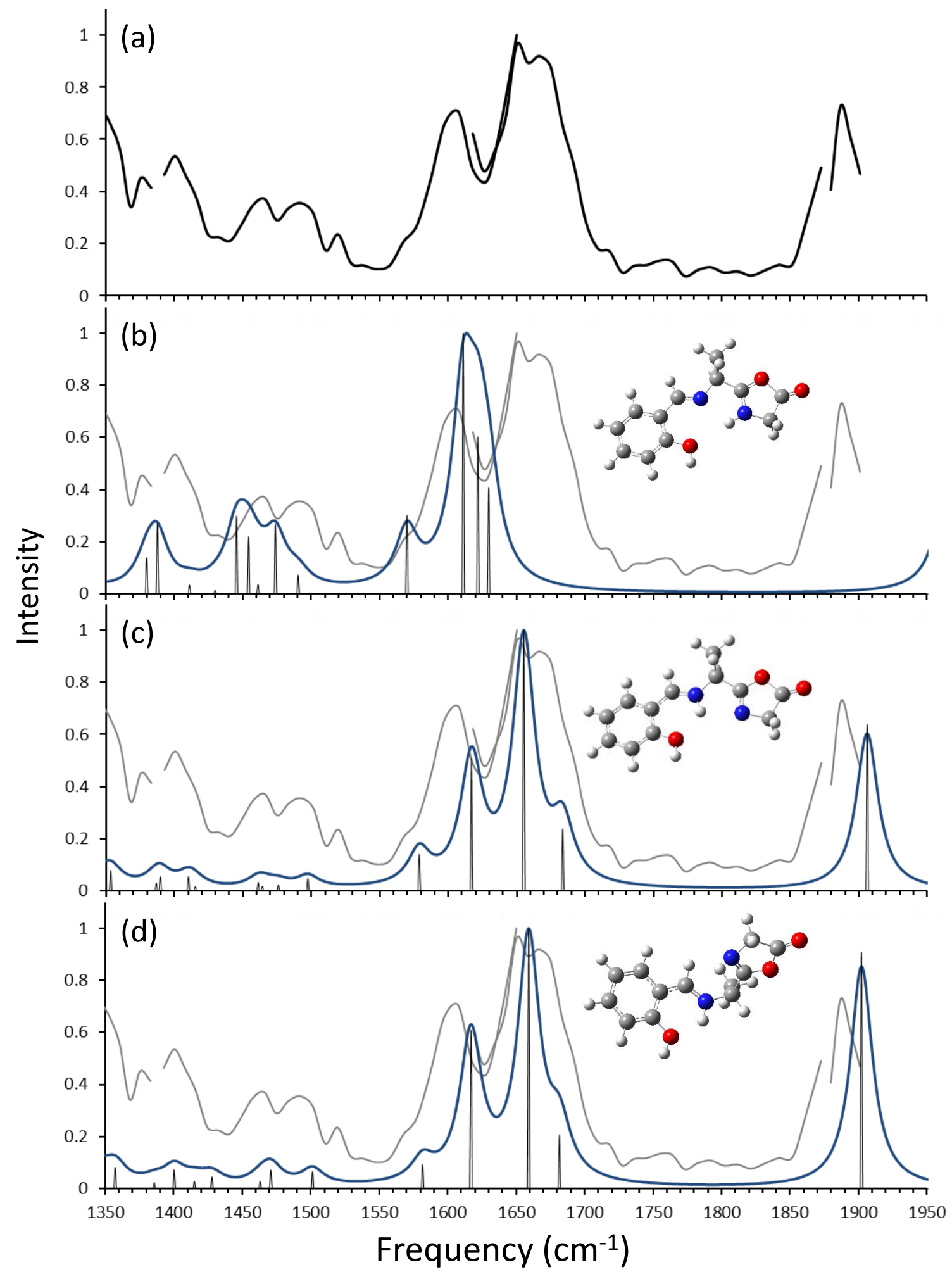

Figure 8. 
Table 1.

$\begin{array}{lcccc} & \text { E } & \text { ZPE } & \text { E+ZPE } & \Delta E \text { (kcal/mol) } \\ \text { I } & -1084.866039 & 0.321767 & -1084.544272 & 0.0 \\ \text { II } & -1084.857113 & 0.322123 & -1084.53499 & 5.8 \\ \text { III } & -1084.850382 & 0.321212 & -1084.52917 & 9.5 \\ \text { IV } & -1084.840454 & 0.322051 & -1084.518402 & 16.2 \\ & & & & \\ \text { V } & -837.4563257 & 0.238487 & -837.217839 & 0.0 \\ \text { VI } & -837.45327 & 0.239226 & -837.214044 & 2.4 \\ \text { VII } & -837.4300069 & 0.238536 & -837.191471 & 16.5 \\ \text { VIII } & -837.3679685 & 0.236842 & -837.131127 & 54.4 \\ \text { IX } & -837.4127483 & 0.254032 & -837.17441 & 27.3 \\ \text { X } & -837.365689 & 0.237762 & -837.127927 & 56.4 \\ & & & & \\ \text { XI } & -800.2580142 & 0.237665 & -800.020349 & 12.0 \\ \text { XII } & -800.2786806 & 0.239163 & -800.039517 & 0.0 \\ \text { XIII } & -800.2756077 & 0.239432 & -800.036176 & 2.1\end{array}$

